\title{
The use of remote sensing for reliable estimation of net radiation and its components: a case-study for contrasting land covers in an agricultural hotspot of the Brazilian semiarid region
}

\section{Article}

Accepted Version

Creative Commons: Attribution-Noncommercial-No Derivative Works 4.0

Ferreira, T. R., da Silva, B. B., de Moura, M. S. B., Verhoef, A. and Nobrega, R. L. B. (2020) The use of remote sensing for reliable estimation of net radiation and its components: a casestudy for contrasting land covers in an agricultural hotspot of the Brazilian semiarid region. Agricultural and Forest Meteorology, 291. 108052. ISSN 0168-1923 doi: https://doi.org/10.1016/j.agrformet.2020.108052 Available at https://centaur.reading.ac.uk/90838/

It is advisable to refer to the publisher's version if you intend to cite from the work. See Guidance on citing.

To link to this article DOI: http://dx.doi.org/10.1016/j.agrformet.2020.108052

Publisher: Elsevier

All outputs in CentAUR are protected by Intellectual Property Rights law, including copyright law. Copyright and IPR is retained by the creators or other copyright holders. Terms and conditions for use of this material are defined in 
the End User Agreement.

www.reading.ac.uk/centaur

\section{CentAUR}

Central Archive at the University of Reading

Reading's research outputs online 


\title{
The use of remote sensing for reliable estimation of net radiation and its
}

\section{components: a case-study for contrasting land covers in an agricultural}

\section{hotspot of the Brazilian semiarid region}

\author{
Thomás R. Ferreira ${ }^{1, *}$, Bernardo B. da Silva ${ }^{1}$, Magna S. B. de Moura ${ }^{2}$, Anne Verhoef ${ }^{3}$ and \\ Rodolfo L. B. Nóbrega ${ }^{3,4}$ \\ ${ }^{1}$ Federal University of Campina Grande, Av. Aprígio Veloso, 822, Cidade Universitária, CEP \\ 58420-102, Campina Grande, PB, Brazil \\ ${ }^{2}$ Brazilian Agricultural Research Corporation, Embrapa Tropical Semi Arid, BR 428, Km 152, s/n, \\ Zona Rural, CEP 56302-970, Petrolina, PE, Brazil \\ ${ }^{3}$ The University of Reading, Whiteknights, Reading RG6 6AB, United Kingdom \\ ${ }^{4}$ Imperial College London, Department of Life Sciences, Ascot SL5 7PY, United Kingdom \\ * Correspondence to: thomas.ferreira@ufcg.edu.br; Tel.: +55-083-2101-1202
}

Abstract: This study aims to ascertain the uncertainties related to the spatiotemporal estimation of net radiation, and its components, using remote sensing data. Geographical focus is an irrigated agricultural hotspot of the Brazilian semiarid region, for which we also investigate the impact that contrasting land-cover types have on the upwelling radiation balance components, and hence on net radiation. Instantaneous $\left(R_{n}\right)$ and daily $\left(R_{n, 24}\right)$ values of net radiation were estimated based on OLI/TIRS-Landsat-8 images and key weather variables. In addition, we evaluated two models for downwelling shortwave $\left(\mathrm{R}_{\mathrm{sw}}\right)$, ten models for downwelling longwave radiation $\left(\mathrm{R}_{\mathrm{lw}}\right)$, and two models for derivation of $\mathrm{R}_{\mathrm{n}, 24}$. The accuracy of each model was evaluated with radiation measurements obtained from research quality sensors installed in micrometeorological towers. The best performances were found for the Allen model, Duarte model, and De Bruin model for $\mathrm{R}_{\mathrm{sw}}, \mathrm{R}_{\mathrm{lw}}$, and $R_{n, 24}$, respectively. The contrasting land-use types exhibited substantial differences in the biophysical variables and radiative properties that affect $\mathrm{R}_{\mathrm{n}}$. The albedo for the irrigated crops has average absolute values that are $0.01-0.03$ larger than those found for the pristine caatinga, whereas 
the land surface temperature, LST, is 3-5 degrees smaller. However, $\mathrm{R}_{\mathrm{n}}$ for these two distinctly different surface types was similar, as a result of a considerably lower surface emissivity in the caatinga. For rangeland, the albedo, LST, and hence the upwelling radiation had greater values than those found for the caatinga, which caused reduced values of $\mathrm{R}_{\mathrm{n}}$. The urban areas exhibited the lowest values of $R_{n}$, mainly as a consequence of their high albedo values. We show that when in-situ net radiation data are not available, remote sensing data combined with more readily available in-situ weather data can be used to derive spatiotemporal estimates of $R_{n}$. This facilitates the identification of anthropogenic impacts on the radiation at the land-surface and ultimately the energy balance, including the short-term seasonal and long-term effects.

Keywords: remote sensing; land use change; caatinga; energy balance; longwave radiation; downwelling solar radiation.

\section{Introduction}

The Brazilian semiarid region is predominantly characterized by the Caatinga, a seasonally dry tropical forest, which is ecologically rich. Few studies have addressed the effects of anthropogenic changes on this natural vegetation cover, especially in the context of land-surface climate interactions (e.g. Cunha et al., 2020; Marques et al., 2020). During the past decades, the Caatinga has been extensively affected by anthropogenic land-cover changes, and only a few ecologically important landscapes of this natural habitat remain, of which only $1.3 \%$ is protected by law (CNUC/MMA, 2018). This region is the most populous semiarid territory in the world (IBGE, 2010), and yet one of the most threatened Brazilian natural landscapes; mainly because it comprises originally pristine Caatinga areas that are now affected by desertification, agricultural intensification (both rainfed and irrigated crops), and (over)grazing (pasture). Most of water resources in this region come from the São Francisco River, whose waters supply several municipalities; for human consumption, generation of energy and agricultural activity. The increase of irrigated agriculture in the Caatinga, in particular during recent years, has had positive socio-economic implications but it has also increased conflicts related to water use. 
The anthropogenic activities influence local climate through changes in surface properties and

54

state variables such as albedo and land-surface temperature (Bonan 2008; Gomes et al., 2009; Kvalevag et al., 2010; Li et al., 2019). Therefore, the local and regional atmospheric circulation in the Caatinga has being affected (Correia et al., 2006; Melo et al., 2015). These alterations in biophysical surface variables impact the surface net radiation balance, as observed by Silva et al. (2015) who studied the replacement of woody savanna by agricultural crops and eucalyptus plantation, and by Liu et al. (2019) who investigated the radiative effects of the conversion of croplands to grasslands.

Net radiation $\left(\mathrm{R}_{\mathrm{n}}\right)$ is defined as the balance between incoming (downwelling) and outgoing (upwelling) shortwave and longwave radiation at the surface. The downwelling fluxes are strongly dependent on latitude, solar angle (for shortwave radiation), as well as cloudiness and atmospheric properties such as temperature and vapour pressure, that affect the longwave downwelling flux directly (i.e., air temperature, via Stefan Boltzmann's law) or indirectly through changes in atmospheric emissivity. Important variables for the upwelling radiation fluxes are albedo (shortwave radiation), and land surface temperature and surface emissivity, that together determine the longwave upwelling radiation, again calculated by Stefan Boltzmann's law. All of these atmospheric and surface variables display considerable spatial and temporal variability, which directly affect heat and mass exchanges in the planetary boundary layer (Silva et al., 2015; Kilic et al., 2016).

Estimation of $R_{n}$ is very important in the context of turbulent energy flux estimates (latent heat flux (i.e., evapotranspiration), and sensible heat flux), particularly in those studies devoted to the assessment of evapotranspiration based on remote sensing techniques (Bastiaanssen et al., 1998, 2005; Allen et al., 2007; Silva et al., 2015; Elnmer et al., 2019) and those employing the Bowen ratio method, where $\mathrm{R}_{\mathrm{n}}$ (as a key component of the available energy) is crucial for the reliable calculation of latent and sensible heat fluxes (Verhoef and Campbell, 2005). Reliable values of $R_{n}$ are also required to check the closure of the energy balance when turbulent energy fluxes have been directly determined with the eddy covariance technique, because there may be an underestimation due to the existence of storage of heat in canopies or in the layer below the instrumentation, horizontal advection, errors in the frequency response of sensors, and regional scale heterogeneity that can cause large-scale eddies that are not readily sensed by eddy covariance systems. Therefore, the sum of 
measured latent plus sensible heat fluxes needs to be compared with values of net radiation minus ground heat flux, to assess the magnitude of the non-closure (Jensen and Allen, 2016). $R_{n}$ can be directly determined onsite with net radiometers, which are accurate but expensive and only produce measurements representative of relatively small areas (Jensen and Allen, 2016).

Satellite imagery has been widely used to determine $\mathrm{R}_{\mathrm{n}}$ from field to regional scales, and over heterogeneous areas (Bisht et al., 2005; Allen et al., 2007; Ryu et al., 2008; Bisht and Bras, 2010; Silva et al., 2011; Silva et al., 2015). In this context, various algorithms have been developed to estimate the downwelling shortwave radiation (Zillman, 1972; Allen et al., 2007), downwelling longwave radiation (Sugita and Brutsaert, 1993; Prata, 1996; Bastiaanssen et al., 1998; Duarte et al., 2006; Allen et al., 2007; Kruk et al., 2010; Santos et al., 2011), longwave radiation balance, and radiative properties such as surface emissivity (Tasumi, 2003; Muñoz-Jiménez et al., 2006; Tang and Li, 2008; Teixeira et al., 2009).

For the downwelling shortwave radiation, Bisht et al. (2005), Bisht and Bras (2010), Alados et al. (2011) and Silva et al. (2015) in subtropical regions, and Vancoppenolle et al. (2011) in Antarctica, have obtained good results when applying the model proposed by Zillman (1972). On the other hand, the Mapping Evapotranspiration aT high Resolution with Internalized Calibration (METRIC) model employed by Allen et al. (2007), ensured that for clear sky conditions, the accuracy of METRIC downwelling shortwave radiation was comparable to data measured with a pyranometer sensor mounted on an automated weather station (Allen 1996; ASCE-EWRI 2005; Jensen and Allen, 2016).

Several models are dedicated to estimate the downwelling longwave radiation; Allen et al. (2007), Allen et al. (2011), and Santos et al. (2020) recommend the expression employed in Bastiaanssen et al. (1998). Silva et al. (2015) evaluated nine models of downwelling longwave radiation at the Mogi Guaçu watershed (a subtropical Brazilian basin), and found that the model of Duarte et al. (2006) presented the best performance on the basis of mean errors. Other studies also indicated a good performance of the Duarte et al. (2006) model (in Korea: Choi, 2013; in the Brazilian southeastern region: Kruk et al., 2010; and in Argentina: Carmona et al., 2014). Santos et al. (2011) proposed a model that showed errors less than $1.0 \%$, in a banana orchard located in the semiarid region of Northeast Brazil. 
Regarding daily net radiation, Bastiaanssen et al. (2000) recommended the use of the expression employed by De Bruin (1987) in remote sensing applications (in this case Landsat images were employed). Silva et al. (2015), when using this model with TM Landsat 5 images, found small mean errors, at the Mogi Guaçu watershed (mentioned above), in a sugarcane field and in a Cerrado forest area. Trigo et al. (2018) successfully validated a Priestley-Taylor (Priestley and Taylor, 1972) grass reference evapotranspiration product (that uses a Meteosat Second Generation shortwave radiation product, and the De Bruin (1987) equation), in a non-irrigated grass area (Cabauw, The Netherlands), and showed a modest bias of $-0.4 \mathrm{~mm} /$ day. Another method to obtain daily net radiation was developed by Bisht et al. (2005); it has been used in several remote sensing studies (Bisht and Bras, 2010; Bisht and Bras, 2011; Ruhoff et al., 2012; Zhu et al., 2017; Wang et al., 2019).

However, there is a lack of applications and validation of those models in the framework of the assessment of the effect of land-cover change on land-surface radiation components for Brazilian semiarid conditions. A better quantification of regional net radiation for evapotranspiration estimates resources. Hence, the aims of this study are: (a) to assess the uncertainties related to the estimation of net radiation components from remote sensing methods, and (b) to evaluate the impact that contrasting land-cover types have on the radiation balance components in an agricultural hotspot of the Brazilian semiarid region, using remote sensing and in-situ data. This is the first study of its kind in this region.

\section{Materials and Methods}

\subsection{Study area: Climatology and land use (sampling)}

The study area is located in the Brazilian Caatinga domain, an area that originally encompassed approximately $900,000 \mathrm{~km}^{2}$. Over the past decades large pristine Caatinga areas have been cleared and replaced by rainfed (mostly) and irrigated agriculture, while in other areas grasses took over and grazing pasture became the dominant land-cover type. Within the Caatinga, we selected an area of $7,366 \mathrm{~km}^{2}$, which is situated in the Low-Middle São Francisco river watershed, between the federal states of Pernambuco (PE) and Bahia (BA). The selected area includes part of the São Francisco 
River, urban areas of Petrolina and Juazeiro towns, Caatinga and pasture vegetation, and irrigated crops (about 70,000 hectares) (Fig. 1). Although irrigated agriculture is not the most common type of agriculture found in the Brazilian semiarid region, it is predominant in the area of study due to the easy access to the São Francisco river, that supplies the irrigation water. The land-use data were produced by MapBiomas (Projeto MapBiomas, 2019), that uses automatic classification procedures applied to satellite images to generate coverage and land-use data. Note that information on rainfed agricultural land use is not available in MapBiomas (most likely because the rainfed areas are too small in that region to be detected by Landsat), hence this land use was not considered in our study. The climatology for Petrolina is presented in Table S1 for the 1981-2010 period, the procedures for obtaining it are in accordance with World Meteorological Organization WMO technical recommendations (WMO station code: 81991; WMO; 1989; INMET, 2018).

With the aim to evaluate the impact that land-use changes have had/could have on the land surface state variables and the radiation balance of the original Brazilian Caatinga, we selected 100 random data points (for the variables given below) for caatinga vegetation, irrigated agriculture, pasture, and urban infrastructure (i.e., a total of 400 points). This procedure provided a common basis for comparison between the landcover types, using the same spatial sampling structure, and followed the methodology of other studies (e.g. Raynolds et al, 2006; Lin et al., 2014; Robinson et al., 2017; Hoagland et al., 2018). The random points were generated for each land-use type using a random points tool of QGIS 3.6 Noosa (QGIS, 2020), a reliable and practical tool also utilized in other studies (Waldmann-Selsam et al., 2016; Wijesingha et al., 2019; Urrutia et al., 2020), that helps avoid bias. These data were used to create box-plots for land surface temperature (LST), net radiation at the time

157 of satellite overpass ( $\mathrm{R}_{\mathrm{n}, \mathrm{over}}$, see Eq. 1), Normalized Difference Vegetation Index - NDVI (Rouse et 158 al., 1974) albedo, and surface emissivity $\varepsilon_{0}$, based on MapBiomas classification 

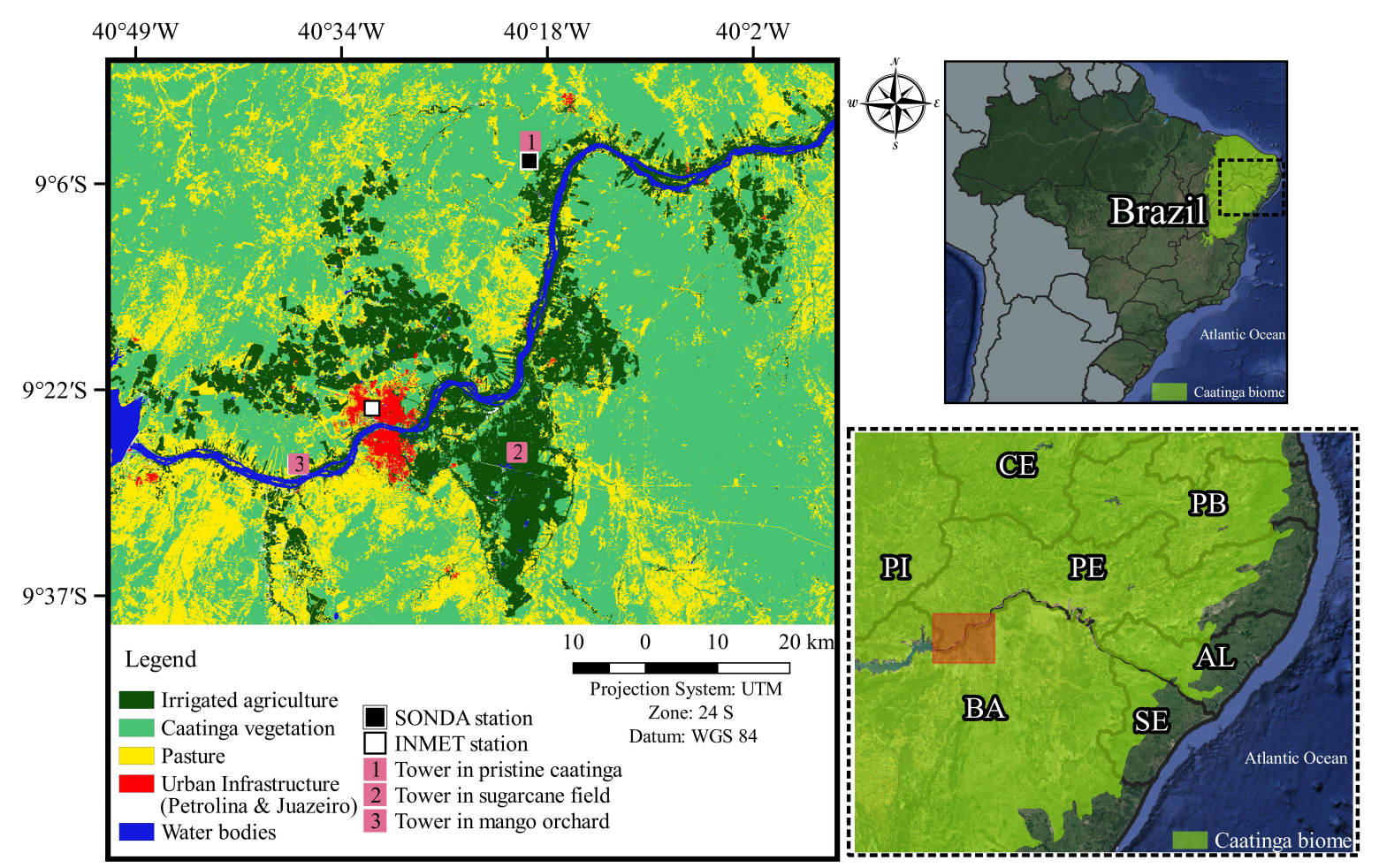

Figure 1. Coverage and land use map of the study area. The subsets indicate the four contrasting land-cover types that were studied. Data were obtained from 'Projeto MapBiomas'.

The maximum daily air temperature $\left(\mathrm{T}_{\max }\right.$ ), of the study area (see Table $\mathrm{S} 1$ ) ranges from $29.7{ }^{\circ} \mathrm{C}$ (July) to $34.2{ }^{\circ} \mathrm{C}$ (November), with an annual mean of $32.3{ }^{\circ} \mathrm{C}$. The mean annual minimum air temperature $\left(\mathrm{T}_{\min }\right)$ is $22.2{ }^{\circ} \mathrm{C}$, and varies between $20.0{ }^{\circ} \mathrm{C}$ (July) and $23.5^{\circ} \mathrm{C}$ (December). The mean daily sunshine hours duration varies from $7.3 \mathrm{~h}$ (June) to $9.2 \mathrm{~h}$ (September-October). Mean monthly rainfall ranges between $1.4 \mathrm{~mm}$ (August) to $114.1 \mathrm{~mm}$ (March); most of this (70.4\%) falls between January and April with an annual mean of $482.6 \mathrm{~mm}$ (See Table S1 in the supplementary material). The high values of daily downwelling shortwave radiation (up to $36 \mathrm{MJ} \mathrm{m}^{-2}$ ), low values of air relative humidity (from $43.8 \%$ in October to $60.2 \%$ in June), and relatively high wind speeds ( $3 \mathrm{~m} \mathrm{~s}^{-}$ ${ }^{1}$ on average) result in an annually averaged Class A pan evaporation of $9.2 \mathrm{~mm} \mathrm{day}^{-1}$, with accumulated monthly values ranging between $216.8 \mathrm{~mm}$ (April) and $387.8 \mathrm{~mm}$ (October). The annual reference evapotranspiration $\left(\mathrm{ET}_{0}\right)$ for the 30 -year period is $1887 \mathrm{~mm}$. Based on these data the local climate can be classified as semi-arid to arid. 


\subsection{Satellite images and weather data}

We used the Operational Land Imager (OLI) Collection 1 Level-1 bands $2(0.450-0.51 \mu \mathrm{m}), 3$ $(0.53-0.59 \mu \mathrm{m})$ and $4(0.64-0.67 \mu \mathrm{m})$ in the visible spectrum, $5(0.85-0.88 \mu \mathrm{m})$ in the near-infrared, $6(1.57-1.65 \mu \mathrm{m})$ and $7(2.11-2.29 \mu \mathrm{m})$ in the shortwave infra-red, all with a spatial resolution of 30 $\mathrm{m}$, as well as the Thermal Infrared Sensor (TIRS) band 10 with a spatial resolution of $100 \mathrm{~m}$. We used thirty OLI/TIRS Landsat 8 images, path 217 and rows 66 and 67, for the period from 2013-2019 (for the dates and times of the satellite overpass, see the first column in Table S2) (USGS, 2018). We used the Level-1 Quality Assessment product of Landsat 8 to ensure that no bad satellite data were included in the processing.

One-minute data of air temperature $-\mathrm{T}_{\mathrm{a}}\left({ }^{\circ} \mathrm{C}\right)$, relative humidity- $\mathrm{RH}(\%)$, atmospheric pressure $-\mathrm{P}_{\mathrm{a}}(\mathrm{kPa})$, downwelling shortwave radiation $-\mathrm{R}_{\mathrm{sw}, \mathrm{obs}}\left(\mathrm{W} \mathrm{m}^{-2}\right)$, and downwelling longwave radiation- $\mathrm{R}_{\mathrm{lw}, \mathrm{obs}}\left(\mathrm{W} \mathrm{m}^{-2}\right)$ were obtained from Petrolina Station (hereinafter referred to as SONDA station; part of the Baseline Surface Radiation Network (BSRN)). For details of sensors and data quality control see Driemel et al. (2018). For the present study, we used the one-minute data at the satellite overpass times (Table S2) to calculate variables required for the calculation of $\mathrm{R}_{\mathrm{n}, \mathrm{over}}$.

Measurements from 4-component net radiometers (CNR1 model Kipp-Zonen, Delft, the Netherlands), installed in a micrometeorological tower (at $8 \mathrm{~m}$ height) in irrigated sugarcane (SC), in irrigated mango orchard (MO), at $6 \mathrm{~m}$, and at $14 \mathrm{~m}$ in a pristine caatinga (PC) (Fig. 1), were used to validate the instantaneous and daily $R_{n}$ results derived from OLI/TIRS Landsat 8 images. Ten images (2013-2015) were used for SC (in-situ $\mathrm{R}_{\mathrm{n}}$ data were not available for the other five days for which images where available during this period), eight (2017-2019) for $M O$ (in-situ $R_{n}$ data were not available for the other four days) and sixteen (2015-2019) for PC (in-situ $R_{n}$ data were not available for the other six days). The CNR1 measurements were collected every 30 seconds, and averages were recorded at 30-minute (SC and $\mathrm{PC}$ ) and 10-minute (MO) intervals by a datalogger (CR23X for sugarcane, CR1000 for Caatinga, and CR5000 for mango orchard, manufactured by Campbell Scientific., Logan, UT, USA).

\subsection{Determination of instantaneous net radiation}



calculated using Eq. 1 (Allen et al., 2007; Silva et al., 2015):

$$
R_{n, \text { over }}=(1-\alpha) R_{s w}-R_{e m i}+\varepsilon_{0} R_{l w}
$$

203

where $\alpha$ (dimensionless) is the surface broadband albedo (dimensionless), $\mathrm{R}_{\mathrm{sw}}\left(\mathrm{W} \mathrm{m}^{-2}\right.$ ) is the downwelling shortwave radiation (estimated by different parameterizations, subsection 2.3.2), $\mathrm{R}_{\mathrm{emi}}$ $\left(\mathrm{W} \mathrm{m}{ }^{-2}\right)$ is the longwave radiation emitted by the surface, $\varepsilon_{0}$ is the pixel surface emissivity, and $\mathrm{R}_{\mathrm{lw}_{\mathrm{w}}}(\mathrm{W}$ $\mathrm{m}^{-2}$ ) is the downwelling longwave radiation emitted by the atmosphere, all obtained at the time of the satellite overpass.

The instantaneous net radiation at the surface- $-\mathrm{R}_{\mathrm{n}}(\mathrm{t})\left(\mathrm{W} \mathrm{\textrm {m } ^ { - 2 }}\right)$ at any time $\mathrm{t}$ (local solar time) of the diurnal cycle (from sunrise to sunset, only for $R_{n}(t)>0$ ) can be obtained based on the assumption that the diurnal variability of net radiation follows a sinusoidal pattern (Bisht et al., 2005):

$$
R_{n}(t)=R_{n, \max } \sin \left[\left(\frac{t-t_{\text {rise }}}{t_{\text {set }}-t_{\text {rise }}}\right) \pi\right]
$$

where $R_{n, \max }\left(\mathrm{W} \mathrm{m}^{-2}\right)$ is the maximum daily net radiation and $t_{\text {rise }}$ and $t_{\text {set }}$ are the times when $R_{n}(t)$ becomes positive and negative, respectively, throughout the day (we assume that $\mathrm{t}_{\text {rise }}$ occurs 50 minutes after sunrise and $t_{\text {set }}$ occurs 50 minutes before sunset). $\mathrm{R}_{\mathrm{n} \text {, max }}$ was determined according to (Bisht et al., 2005):

$$
R_{n, \max }=\frac{R_{n, \text { over }}}{\sin \left[\left(\frac{t_{\text {over }}-t_{\text {rise }}}{t_{\text {set }}-t_{\text {rise }}}\right) \pi\right]}
$$

\subsubsection{Broadband albedo}

The broadband surface albedo - $\alpha$, for each pixel with atmospheric correction, was obtained according to the following expression (Bastiaanssen et al., 1998; Allen et al., 2007; Silva et al., 2016):

$$
\alpha=\left(\frac{\alpha_{t o a}-a}{\tau_{s w}^{2}}\right)
$$

where $\alpha_{\text {toa }}$ is the broadband albedo at the top of atmosphere, i.e., before atmospheric correction, $a$ is the atmospheric reflectance (set to 0.03, as used in many studies (Bastiaanssen et al., 2000; Silva et 
al., 2015; Silva et al., 2016)) and $\tau_{\mathrm{sw}}$ is the atmospheric transmissivity for clear sky conditions (see Eq.

222 7). $\alpha_{\text {toa }}$ consists of a linear combination of the spectral reflectance of the six reflective OLI bands, according to Silva et al. (2016):

$$
\alpha_{\text {toa }}=0.300 r_{2}+0.277 r_{3}+0.233 r_{4}+0.143 r_{5}+0.036 r_{6}+0.001 r_{7}
$$

where $r_{2}-r_{7}$ are the reflectivities of OLI spectral bands $2-7$, respectively, each one of them obtained using Eq. 6:

$$
r_{b}=\left(\frac{A d d_{b}+M u l t_{b} D N}{\cos Z d r}\right)
$$

where the terms $\operatorname{Add}_{\mathrm{b}}$ and Mult $_{\mathrm{b}}$ belong to the radiometric rescaling group, specifically the reflectance_add_band (equal to -0.1) and reflectance_mult_band (equal to 0.00002), respectively, presented in the metadata of each OLI - Landsat 8 image, $\mathrm{Z}$ is the solar zenith angle, and $\mathrm{dr}$ is the relative Earth-Sun distance squared (dimensionless), see Table S2. Parameter $\tau_{\mathrm{sw}}$ is obtained from (Allen et al., 2007):

$$
\tau_{s w}=0.35+0.627 \exp \left[\frac{-0,00146 P_{a}}{K_{t} \cos Z}-0.075\left(\frac{W}{\cos Z}\right)^{0.4}\right]
$$

in which $\mathrm{K}_{\mathrm{t}}$ is the atmospheric turbidity coefficient, $\mathrm{P}_{\mathrm{a}}$ is atmospheric pressure (kPa; see Table 1$)$, and W is precipitable water (mm), defined by the following equation (Garrison and Adler, 1990):

$$
W=10\left[1.4 e_{a}\left(\frac{P_{a}}{P_{s m l}}\right)+0.21\right]
$$

where $e_{a}$ is the partial pressure of atmospheric water vapor $(\mathrm{kPa})$, obtained from $\mathrm{RH}$ and $\mathrm{T}_{\mathrm{a}}$ measured at the SONDA site (see Table S2 and Section 2.2), $\mathrm{P}_{\mathrm{a}}$ is the atmospheric pressure (in $\mathrm{kPa}$, see Table $\mathrm{S} 2)$, and $\mathrm{P}_{\mathrm{sml}}$ is the atmospheric pressure at mean sea level (101.3 $\left.\mathrm{kPa}\right)$.

\subsubsection{Downwelling shortwave radiation assessment}

The downwelling shortwave radiation $-\mathrm{R}_{\mathrm{sw}}\left(\mathrm{W} \mathrm{m}^{-2}\right)$, at the satellite overpass time, for clear-sky condition was estimated by parameterizations developed by Allen et al. (2007)— $\mathrm{R}_{\mathrm{sw}, \mathrm{Aln}}$ (referred to as Allen model) and Zillman (1972) $-\mathrm{R}_{\mathrm{sw}, \mathrm{Zlm}}$ (referred to as Zillman model), according to the following equations: 


$$
\begin{gathered}
R_{S w, A l n}=S_{o} \cos Z d_{r} \tau_{s w} \\
R_{s w, Z l m}=\frac{S_{0} \cos ^{2} Z}{1.085 \cos Z+e_{a}(2.7+\cos Z) 10^{-3}+\beta}
\end{gathered}
$$

241

242

where $\mathrm{S}_{0}$ is the solar constant $\left(1361 \mathrm{~W} \mathrm{~m}^{-2}\right)$ and $\beta$ is an adjustment coefficient that was evaluated for two different values $\beta=0.10\left(\mathrm{R}_{\mathrm{sw}, Z .1}\right.$, originally adopted by Zillman, 1972) and $\beta=0.2\left(\mathrm{R}_{\mathrm{sw}, Z .2}\right.$ suggested by Bisht et al., 2005; Bisht et al., 2010; and Silva et al., 2015); all other symbols are as defined before.

\subsubsection{Estimation of upwelling and downwelling longwave radiation}

The upwelling longwave radiation emitted by the surface at the satellite overpass $-\mathrm{R}_{\mathrm{emi}}\left(\mathrm{W} \mathrm{m} \mathrm{m}^{-2}\right)$ was calculated according to Stefan-Boltzmann's Law:

$$
R_{e m i}=\varepsilon_{0} \sigma L S T^{4}
$$

where $\sigma$ is the Stefan-Boltzmann constant, $\varepsilon_{0}$ is the pixel surface emissivity, and LST is the land surface temperature $(\mathrm{K})$, which was obtained using the spectral radiance of band 10 of the TIRS $-\mathrm{L}_{\lambda 10}$ $\left(\mathrm{W} \mathrm{m}{ }^{-2} \mathrm{sr}^{-1} \mu \mathrm{m}^{-1}\right.$ ) and the emissivity at the nearest band $-\varepsilon_{\mathrm{NB}}$, through the inverted Planck Law (Markham and Barker, 1986):

$$
L S T=\frac{K_{2}}{\ln \left(\frac{\varepsilon_{N B} K_{1}}{L_{\lambda, 10}}+1\right)}
$$

where $K_{1}$ and $K_{2}$ are radiation constants specific to TIRS-Landsat 8 band 10 , equaling $774.89 \mathrm{~W} \mathrm{~m}^{-2}$ $\mathrm{sr}^{-1} \mu \mathrm{m}^{-1}$ and $1321.08 \mathrm{~K}$, respectively. The surface emissivity across the entire longwave radiation spectrum $-\varepsilon_{0}$ and the one associated with the thermal band spectrum, $\varepsilon_{\mathrm{NB}}$, were calculated based on the Leaf Area Index, LAI, according to Tasumi (2003), for each pixel.

The atmospheric downwelling longwave radiation $-\mathrm{R}_{\mathrm{lw}}\left(\mathrm{W} \mathrm{m}^{-2}\right)$ was calculated using StefanBoltzmann's Law (analogous to Eq. 11): 


$$
R_{l w}=\varepsilon_{a} \sigma T_{a}^{4}
$$

where LST in Eq. 11 was substituted by $\mathrm{T}_{\mathrm{a}}(\mathrm{K})$, measured at the SONDA station of Petrolina, and the surface emissivity was replaced by the atmospheric emissivity- $\varepsilon_{\mathrm{a}}$. Parameter $\varepsilon_{\mathrm{a}}$ was determined with the expression that provided the best estimate of $\mathrm{R}_{\mathrm{lw}}$ among ten different models, when compared with pyrgeometer measurements at the SONDA station. The various expressions used to compute $\varepsilon_{\mathrm{a}}$ are listed in Table 1. Note that those equations by Brutsaert (1975), Sugita and Brutsaert (1993), Duarte et al. (2006), Kruk et al. (2010), and Santos et al. (2011) are in fact the same equation but with different parameter constants. All models we tested required weather data $\left(T_{a}, R H\right.$, and $\left.P_{a}\right)$ collected at the SONDA station at one-minute intervals (Table S2).

Table 1. Different models evaluated for clear-sky atmospheric emissivity- $\varepsilon_{a}$ (dimensionless) determination based on atmospheric vapor pressure $-\mathrm{e}_{\mathrm{a}}(\mathrm{hPa})$ and air temperature $-\mathrm{T}_{\mathrm{a}}(\mathrm{K})$ data (see Table S2)

\begin{tabular}{ll}
\hline Author(s) & Equation \\
\hline Swinbank (1963) & $\varepsilon_{a}=9.365 \cdot 10^{-6} \cdot T_{a}^{2}$ \\
Idso and Jackson (1969) & $\varepsilon_{a}=1-0.261 \exp \left[-7.77 \cdot 10^{-4}\left(273-T_{a}\right)^{2}\right]$ \\
Brutsaert (1975) & $\varepsilon_{a}=0.643\left(\frac{e_{a}}{T_{a}}\right)^{1 / 7}$ \\
Idso (1981) & $\varepsilon_{a}=0.70+5.95 \cdot 10^{-7} e_{a} \exp \left(\frac{1500}{T_{a}}\right)$ \\
Sugita and Brutsaert (1993) & $\varepsilon_{a}=0.714\left(\frac{e_{a}}{T_{a}}\right)^{0.0687}$ \\
Prata (1996) & $\varepsilon_{a}=\left\{1-(1+\varphi) \exp \left[-(1.2+3.0 \varphi)^{0.5}\right]\right\}$ \\
Bastiaanssen et al. (1998) & with $\varphi=0.465\left(\frac{e_{a}}{T_{a}}\right)$ \\
Duarte et al. (2006) & $\varepsilon_{a}=0.85\left(-\ln \tau_{S W}\right)^{0,09}$ \\
Kruk et al. (2010) & $\varepsilon_{a}=0.625\left(\frac{e_{a}}{T_{a}}\right)^{0.131}$ \\
Santos et al. (2011) & $\varepsilon_{a}=0.576\left(\frac{e_{a}}{T_{a}}\right)^{0.202}$ \\
& $\varepsilon_{a}=0.6905\left(\frac{e_{a}}{T_{a}}\right)^{0.0881}$ \\
\hline
\end{tabular}




$$
R_{n, 24, D e B}=(1-\alpha) R_{s w, 24}-110 \tau_{s w 24}
$$

278

279 where $\alpha$ is the surface broadband albedo (see Eq. 4); $\mathrm{R}_{\mathrm{sw}, 24}\left(\mathrm{~W} \mathrm{~m}^{-2}\right)$ is the downwelling shortwave 280

281

282

283

284

285

286

287

288

289

290

291

292

293

radiation (locally measured at SONDA Station) integrated for 24 hours; and $\tau_{\text {sw24 }}$ is the ratio of the daily downwelling shortwave radiation $-\mathrm{R}_{\mathrm{sw}, 24}\left(\mathrm{MJ} \mathrm{m}^{-2}\right)$ and the daily extraterrestrial solar radiation (at the top of atmosphere) $-\mathrm{R}_{\mathrm{sw}, \text { toa }}\left(\mathrm{MJ} \mathrm{m}^{-2}\right)$. The second term in Eq. 14 accounts for the longwave radiation which reduces $R_{n, 24}$, and the constant 110 is locally calibrated as obtained by De Bruin (1987) and applied satisfactorily by Bastiaanssen et al. (2000) and Silva et al. (2015). We also determined daily net radiation according to the sinusoidal model developed by Bisht et al. (2005) valid only for clear sky days (referred to as Bisht model):

$$
R_{n, 24, B s t}=\frac{2 R_{n, \max }}{\pi}
$$

where $\mathrm{R}_{\mathrm{n} \text {,max }}\left(\mathrm{W} \mathrm{m} \mathrm{m}^{-2}\right)$ is the maximum daily net radiation value, which was obtained by Eq. 3 .

\subsection{Statistical metrics}

The performance of the results was determined by the Mean Errors (Absolute Mean ErrorMAE and relative mean error-MRE), the Root Mean Square Error-RMSE, the Pearson correlation coefficient $-r$ and the Coefficient of Residual Mass-CRM:

$$
\begin{gathered}
M R E=\frac{100}{n} \sum_{i=1}^{n}\left|\frac{X_{e s t}-X_{o b s}}{X_{o b s}}\right| \\
M A E=\frac{1}{n} \sum_{i=1}^{n}\left|X_{e s t}-X_{o b s}\right| \\
R M S E=\left(\frac{\sum_{i}^{n}\left(X_{e s t}-X_{o b s}\right)^{2}}{n}\right)^{\frac{1}{2}} \\
r=\frac{\sum_{i=1}^{n}\left(X_{e s t}-\bar{X}\right)\left(X_{o b s}-\bar{X}\right)}{\left[\sum_{i=1}^{n}\left(X_{e s t}-\bar{X}\right)\left(X_{o b s}-\bar{X}\right)^{2}\right]^{\frac{1}{2}}}
\end{gathered}
$$




$$
C R M=\frac{\sum_{i}^{n}\left(X_{o b s}-X_{e s t}\right)}{\sum_{i}^{n}\left(X_{o b s}\right)}
$$

294

295

296

297

298

299

300

301

302

303

304

305

306

307

where $\mathrm{X}_{\mathrm{obs}}, \mathrm{X}_{\mathrm{est}}$ and $\bar{X}$ correspond to measured, estimated and averaged values of the parameterized variables $\left(R_{l w}, R_{s w}, R_{n}\right.$, and $\left.R_{n, 24}\right)$, and $n$ corresponds to the number of observed and estimated variables.

\section{Results and Discussion}

\subsection{Solar radiation and atmospheric transmittance}

The atmospheric transmittance values $-\tau_{\mathrm{sw}}$ associated with the Landsat 8 overpass times over the studied region are presented in Table S3. Values of $\tau_{\mathrm{sw}}$ ranged between 0.723 (May 30, 2013 - DOY 150) and 0.758 (Oct 5, 2013 - DOY 278), making them generally higher than the daily average transmittance $-\tau_{\mathrm{sw}, 24}$, also presented in the same table. The presence of clouds throughout the day attenuates solar radiation and, thus, reduces $\tau_{\mathrm{sw}, 24}$, which consequently reduces the daily downwelling shortwave radiation $-\mathrm{R}_{\mathrm{sw}, 24}$. Contrasting sky conditions can be appreciated in SONDA data over different seasons (clear sky with $\tau_{\mathrm{sw}, 24}=0.720-$ Fig. $2 \mathrm{a}$ and cloudy sky with $\tau_{\mathrm{sw}, 24}=0.684-$ Fig. $2 \mathrm{~b}$ ).

We had $73 \%$ of the selected dates with $\tau_{\mathrm{sw}, 24}$ higher than 0.7 , representative of clear days, and $27 \%$ with $\tau_{\mathrm{sw}, 24}$ lower than 0.7 (ranging from 0.649 to 0.692 ), i.e. days where some clouds were present.
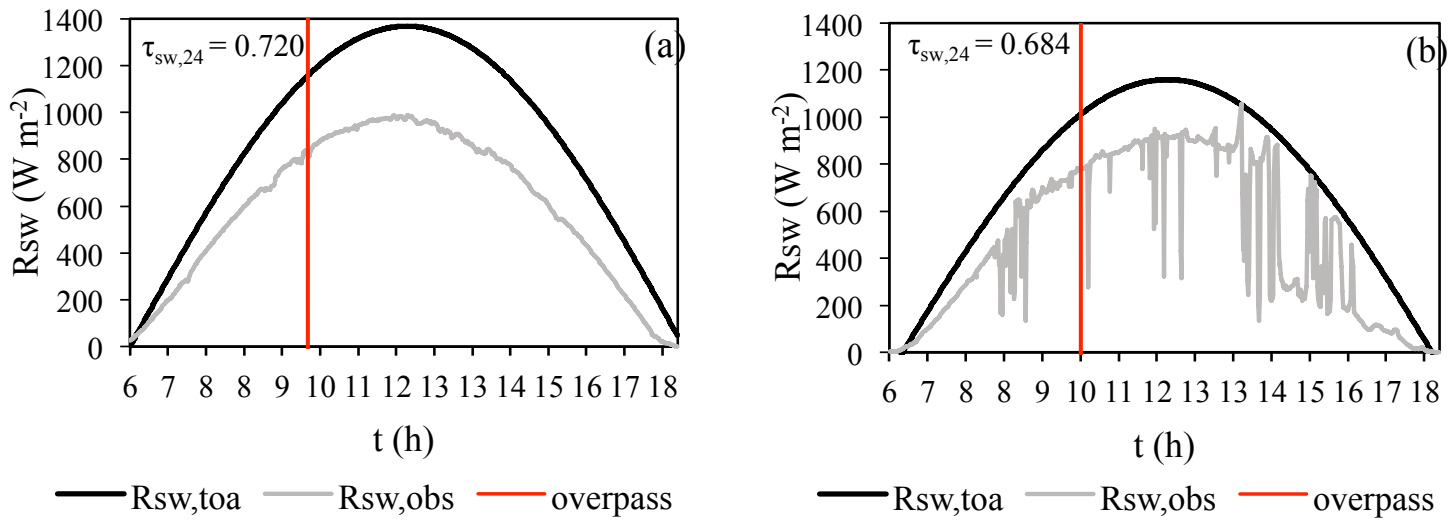

Figure 2. Downwelling shortwave radiation $-\mathrm{R}_{\mathrm{sw}, \mathrm{obs}}\left(\mathrm{W} \mathrm{m}^{-2}\right)$ measured at SONDA station (Petrolina-PE; grey line), downwelling extraterrestrial solar radiation (at the top of atmosphere) $\mathrm{R}_{\mathrm{sw}, \text { toa }}\left(\mathrm{W} \mathrm{m}^{-2}\right.$; black line) and time of satellite overpass (red line) for October 5, 2013 - DOY 278 
(a) and May 22, 2016 - DOY 142 (b).

The measured instantaneous values of downwelling shortwave radiation at the SONDA station-

$\mathrm{R}_{\mathrm{sw}, \mathrm{obs}}$ at time of satellite overpass, ranged between $704 \mathrm{~W} \mathrm{~m}^{-2}$ (June 2, 2014 - DOY 153) and $956 \mathrm{~W}$ $\mathrm{m}^{-2}$ (Oct 27, 2015 - DOY 300) (Table S3). All shortwave models had MRE values smaller than 7\%, but the best model was the $\mathrm{R}_{\mathrm{sw}, \mathrm{Aln}}$, which produced MAE, MRE, and RMSE values of $24.6 \mathrm{~W} \mathrm{~m}^{-2}$, $3.0 \%$, and $32.2 \mathrm{~W} \mathrm{~m}^{-2}$, respectively, and Pearson's correlation coefficient of 0.941 (Fig. 3). The model $R_{\mathrm{sw}, Z .2}$ resulted in values of MAE, MRE, and RMSE close to those calculated for $R_{\mathrm{sw}, \mathrm{Aln}}$, that were $28.7 \mathrm{~W} \mathrm{~m}^{-2}, 3.4 \%$ and $33.8 \mathrm{~W} \mathrm{~m}^{-2}$, and Pearson's correlation coefficient of 0.939. Bisht et al. (2005); Bisht et al. (2010); and Silva et al. (2015) also reported values for $\mathrm{R}_{\mathrm{sw}}$ that were close to their measured values by adopting $\beta=0.2$, although the $\beta$ value originally adopted by Zillman (1972) was compared to $\mathrm{R}_{\mathrm{sw}, \mathrm{Z} .1}$ and less than $1 \%$ compared to $\mathrm{R}_{\mathrm{sw}, \mathrm{Z} .2}$.

There is a large difference between the smallest value (Jun 10, 2017 - DOY 161) of $R_{s w, 24}\left(R_{s w, 24}\right.$ $=230.5 \mathrm{~W} \mathrm{~m}^{-2}$ ) and the highest value (Dec 14, $2015-$ DOY 348) of $\mathrm{R}_{\mathrm{sw}, 24}\left(\mathrm{R}_{\mathrm{sw}, 24}=350.3 \mathrm{~W} \mathrm{~m}^{-2}\right)$

(Table S3), as a result of the seasonality of solar radiation associated to the differences in cloud cover, and also to the transmittance data.

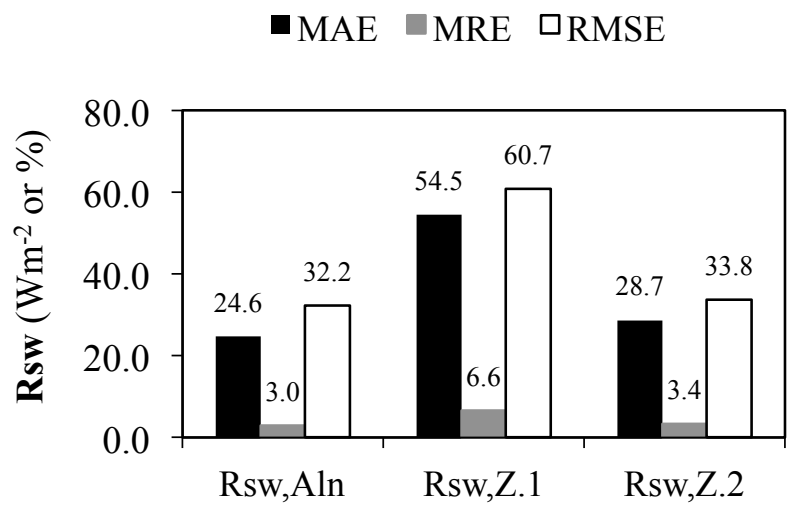

Figure 3. $\mathrm{MAE}\left(\mathrm{W} \mathrm{m}^{-2}\right)$, MRE $(\%)$, and $\operatorname{RSME}\left(\mathrm{W} \mathrm{m}^{-2}\right)$ related to the comparison between instantaneous measured $\mathrm{R}_{\mathrm{sw}}$ and downwelling shortwave radiation obtained with models provided by Allen et al. (2007) $-R_{\mathrm{sw}, A l n}$, and Zillman (1972) $-\mathrm{R}_{\mathrm{sw}, \mathrm{Z}}$ with $\beta=0.10$ and 0.20 , respectively. 
The observed values of atmospheric downwelling longwave radiation $\left(\mathrm{R}_{\mathrm{lw}, \mathrm{obs}}\right)$ and the estimated

ones are in Table S4 in the supplementary material. The accuracy of the models, against measurements taken with an Eppley pyrgeometer, installed at the SONDA station, was tested with the statistical parameters MAE ( $\left.\mathrm{W} \mathrm{m}^{-2}\right)$, MRE (\%), and RMSE ( $\mathrm{W} \mathrm{m}^{-2}$ ) (Fig. 4). The $\varepsilon_{a}$ models that gave the best $\mathrm{R}_{\mathrm{lw}}$ estimates were, in descending order of performance, those of Duarte et al. (2006), Bastiaanssen et al. (1998), Sugita and Brutsaert (1993), and Santos et al. (2011), which resulted in MAE values of $5.9 \mathrm{~W} \mathrm{~m}^{-2}, 10.7 \mathrm{~W} \mathrm{~m}^{-2}, 11.3 \mathrm{~W} \mathrm{~m}^{-2}$, and $11.7 \mathrm{~W} \mathrm{~m}^{-2}$; MRE values of $1.6 \%, 2.9 \%$, $3.1 \%$, and $3.2 \%$; and RMSE values of $7.0 \mathrm{~W} \mathrm{~m}^{-2}, 13.0 \mathrm{~W} \mathrm{~m}^{-2}, 12.5 \mathrm{~W} \mathrm{~m}^{-2}$, and $12.8 \mathrm{~W} \mathrm{~m}^{-2}$, respectively.

Based on the mean errors results we selected the model proposed by Duarte et al. (2006) (referred to as the Duarte model); it showed a relative improvement in estimated $\mathrm{R}_{\mathrm{lw}}$ of around $8 \%$ in relation to the worst performing model (Idso and Jackson, 1969). Silva et al. (2015), who evaluated nine out of the ten models used in the present study at the Mogi Guaçu watershed (a subtropical Brazilian River basin), also concluded that the Duarte model provided the smallest RMSE (7.4 $\left.\mathrm{W} \mathrm{m}^{-2}\right)$ when compared to observed data.

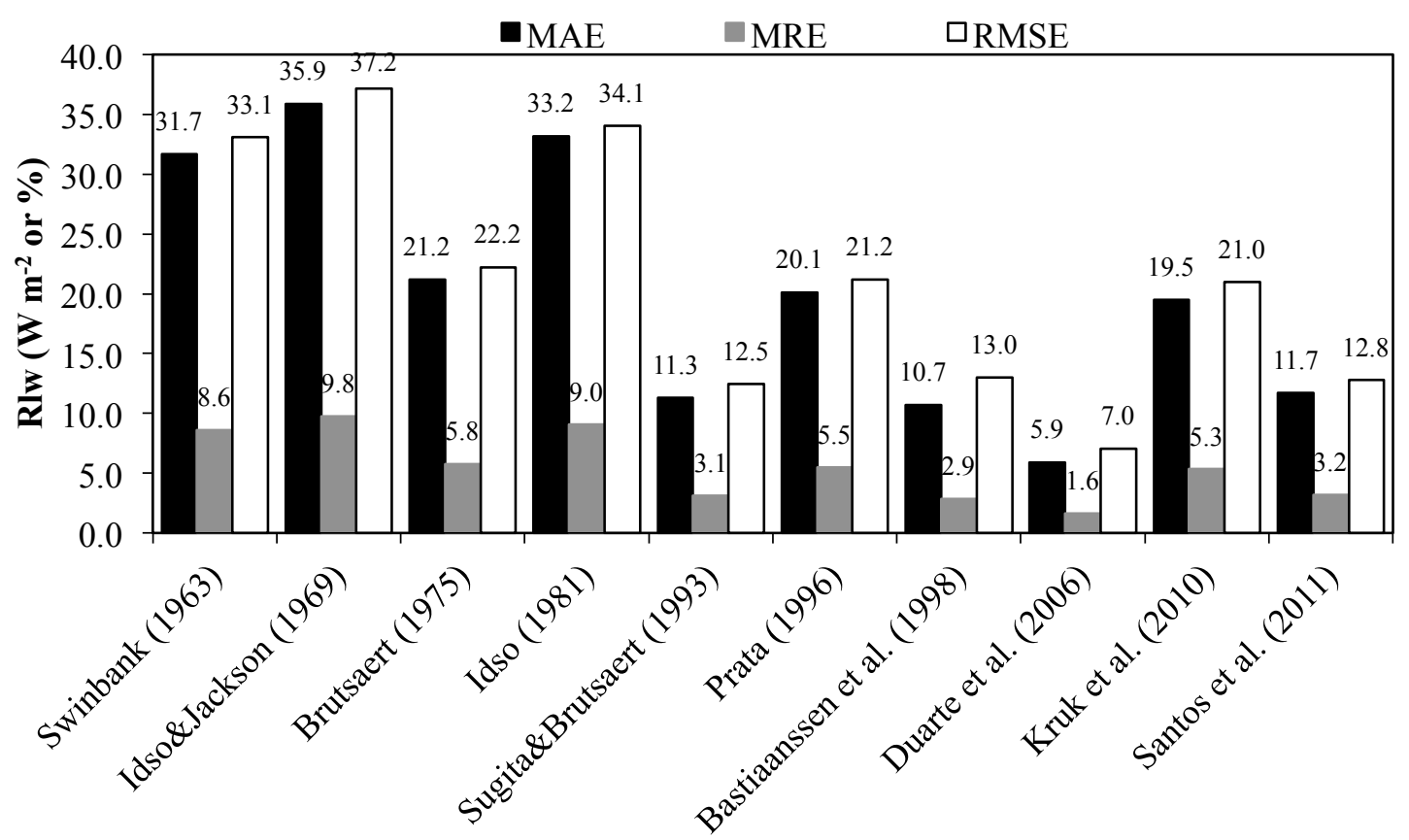

Figure 4. A comparison of the errors (MAE $\left(\mathrm{W} \mathrm{m}^{-2}\right)$, MRE (\%) and RMSE $\left(\mathrm{W} \mathrm{m}^{-2}\right)$ ) between 
values of in-situ measured longwave downwelling radiation, and $\mathrm{R}_{\mathrm{lw}}$ obtained with StefanBoltzmann's Law (Eq. 13), using ten different models of atmospheric emissivity; numbers at the top denote the actual percentages.

\subsection{Overpass and daily net radiation}

The MAE, MRE and RMSE for the comparison between in-situ measured $\mathrm{R}_{n}$ at the time of overpass and $\mathrm{R}_{\mathrm{n} \text {,over }}$ obtained with remote sensing (using Eq. 1, and related equations) were equal to $38.8 \mathrm{~W} \mathrm{~m}^{-2}, 6.3 \%$ and $45.3 \mathrm{~W} \mathrm{~m}^{-2}$ for sugarcane; $60.8 \mathrm{~W} \mathrm{~m}^{-2}, 9.4 \%$ and $65.8 \mathrm{~W} \mathrm{~m}^{-2}$ for pristine caatinga and $84.6 \mathrm{~W} \mathrm{~m}^{-2}, 14 \%$ and $89.3 \mathrm{~W} \mathrm{~m}^{-2}$ for the mango orchard, respectively. Therefore, the estimated instantaneous values of $\mathrm{R}_{\mathrm{n}}$ were very satisfactory for $\mathrm{SC}$ and $\mathrm{PC}$, but not so much for MO.

The accuracy of $R_{n, 24}$ modeled with Eq. 14 and Eq. 15 was compared to the daily $R_{n}$ values measured onsite, using MAE, MRE, and RMSE (Table 2). The results indicate that the values obtained with the original model of Bisht et al. (2005), that is, $R_{n, 24, B s t}$, produced very high errors. The reason for these high errors is that the Bisht model disregards the negative values that occur during the night period and part of the daytime period. This method considers the daily value to be the $R_{n}$ value integrated over the instances for which $\mathrm{R}_{\mathrm{n}}>0$, and divides it by the interval of time corresponding to that period. Instead, when we divide the integrated value for the time period during which $R_{n}>0$, by the time corresponding to the entire daily period (86400 seconds), referred to as Bisht's corrected method, the error indicator values decrease considerably, although they are still relatively large. In contrast, when using the $\mathrm{R}_{\mathrm{n}, 24 \text {,DeB }}$ model, in the same way as proposed in the Surface Energy Balance Algorithm for Land - SEBAL (Bastiaanssen et al., 2000), the results were very satisfactory, even for the mango orchard, with MRE reduced from 14\% (at the overpass) to 9.3\% (24 hours).

Table 2. MAE $\left(\mathrm{W} \mathrm{m} \mathrm{m}^{-2}\right)$, MRE $(\%)$, and RMSE $\left(\mathrm{W} \mathrm{m}^{-2}\right)$ of $\mathrm{R}_{\mathrm{n}}$ estimated by Eq $14-\mathrm{R}_{\mathrm{n}, 24, \mathrm{DeB}}$ and 361 Eq. $15-\mathrm{R}_{\mathrm{n}, 24, \mathrm{Bst}}$ compared with at the sugarcane field (SC), pristine caatinga (PC) and mango orchard (MO)

\begin{tabular}{|c|c|c|c|c|c|c|c|c|c|}
\hline & \multicolumn{3}{|c|}{ Bisht method } & \multicolumn{3}{|c|}{ Bisht's method corrected } & \multicolumn{3}{|c|}{ De Bruin method } \\
\hline & $\begin{array}{l}\mathrm{R}_{\mathrm{n}, 24} \\
\mathrm{SC}\end{array}$ & $\begin{array}{l}\mathrm{R}_{\mathrm{n}, 24} \\
\mathrm{PC}\end{array}$ & $\begin{array}{l}\mathrm{R}_{\mathrm{n}, 24} \\
\mathrm{MO}\end{array}$ & $\begin{array}{l}\mathrm{R}_{\mathrm{n}, 24} \\
\mathrm{SC}\end{array}$ & $\begin{array}{l}\mathrm{R}_{\mathrm{n}, 24} \\
\mathrm{PC}\end{array}$ & $\begin{array}{l}\mathrm{R}_{\mathrm{n}, 24} \\
\mathrm{MO}\end{array}$ & $\begin{array}{l}\mathrm{R}_{\mathrm{n}, 24} \\
\mathrm{SC}\end{array}$ & $\begin{array}{l}\mathrm{R}_{\mathrm{n}, 24} \\
\mathrm{PC}\end{array}$ & $\begin{array}{l}\mathrm{R}_{\mathrm{n}, 24} \\
\mathrm{MO}\end{array}$ \\
\hline MAE & 316.2 & 288.8 & 252.9 & 44.6 & 23.9 & 22.7 & 8.2 & 9.7 & 14.5 \\
\hline MRE & 193.5 & 161.1 & 160.4 & 28.0 & 14.2 & 15.0 & 4.9 & 5.5 & 9.3 \\
\hline
\end{tabular}


In a different climatic region, Silva et al. (2015) obtained MAE, MRE, and RMSE values equal to $8.3 \mathrm{~W} \mathrm{~m}^{-2}, 8.4 \%$, and $10.4 \mathrm{~W} \mathrm{~m}^{-2}$, respectively, for a sugarcane plantation, and $6.5 \mathrm{~W} \mathrm{~m}^{-2}, 6.3 \%$, and $8.5 \mathrm{~W} \mathrm{~m}^{-2}$, respectively, in a Cerrado forest formation, using $\mathrm{R}_{\mathrm{n}, 24, \mathrm{DeB}}$ model. The RMSE values obtained by Bisht et al. (2005) (Southern Great Plains, in USA), Ryu et al. (2008) (flat farmland site and rugged forest in South Korea), Wang and Liang (2009) (grassland, cropland, and desert land cover, in USA), Bisht and Bras (2010) (Southern Great Plains, in USA), and Jin et al. (2011) (deciduous broadleaf forest, mixed forest, evergreen needleleaf forest and Shrubland, in USA) were all higher than those obtained in the present study.

It is important to consider that the in-situ net radiometer instrument has an accuracy of $2.5 \%$ for instantaneous measurements (note that we use averages that were recorded at 30-minute intervals for SC and PC towers, and at 10-minute intervals in MO tower), increasing to $10 \%$ for daily measurements (Silva et al., 2015). The same authors considered that, depending on the height of the in-situ radiometer, the spatial resolution of TM and OLI/TIRS images is compatible with the coverage area of the measurements performed with a 4-component radiometer. The radiometer installed on the micrometeorological towers were 6,8 and 14 meters above the ground for $\mathrm{MO}$, SC and PC which corresponds to a field of view of 11304, 20096 and $61544 \mathrm{~m}^{2}$ respectively (considering a field of vision of $180^{\circ}$ ). Hence, it is appropriate to compare measurements of in-situ $R_{n}$ against estimates by remote sensing (with resolution of 30-100 m, i.e. areas of 900 to $10,000 \mathrm{~m}^{2}$ per pixel).

In Fig. 5, we show the values of the daily net radiation measured at the $\mathrm{SC}, \mathrm{PC}$ and $\mathrm{MO}\left(\mathrm{R}_{\mathrm{n}, 24, \mathrm{obs}}\right)$ pixels versus the values obtained by Eq. $14\left(\mathrm{R}_{\mathrm{n}, 24, \mathrm{DeB}}\right)$ and Eq. 15 , corrected as explained above, $\left(R_{n, 24, B s t}\right)$. It is clear that there is greater agreement between the measured data and those of $R_{n, 24, D e B}$, which resulted in a greater Pearson correlation coefficient $(r)$ and smaller Coefficient of Residual Mass (CRM), with $r$ ranging from 0.881 to 0.943 , and CRM between 0.008 and 0.083 . The correlation between the measurements of $R_{n, 24}$ with those obtained according to $R_{n, 24, B s t}$ were lower 

measured data considerably, for the studied surfaces.

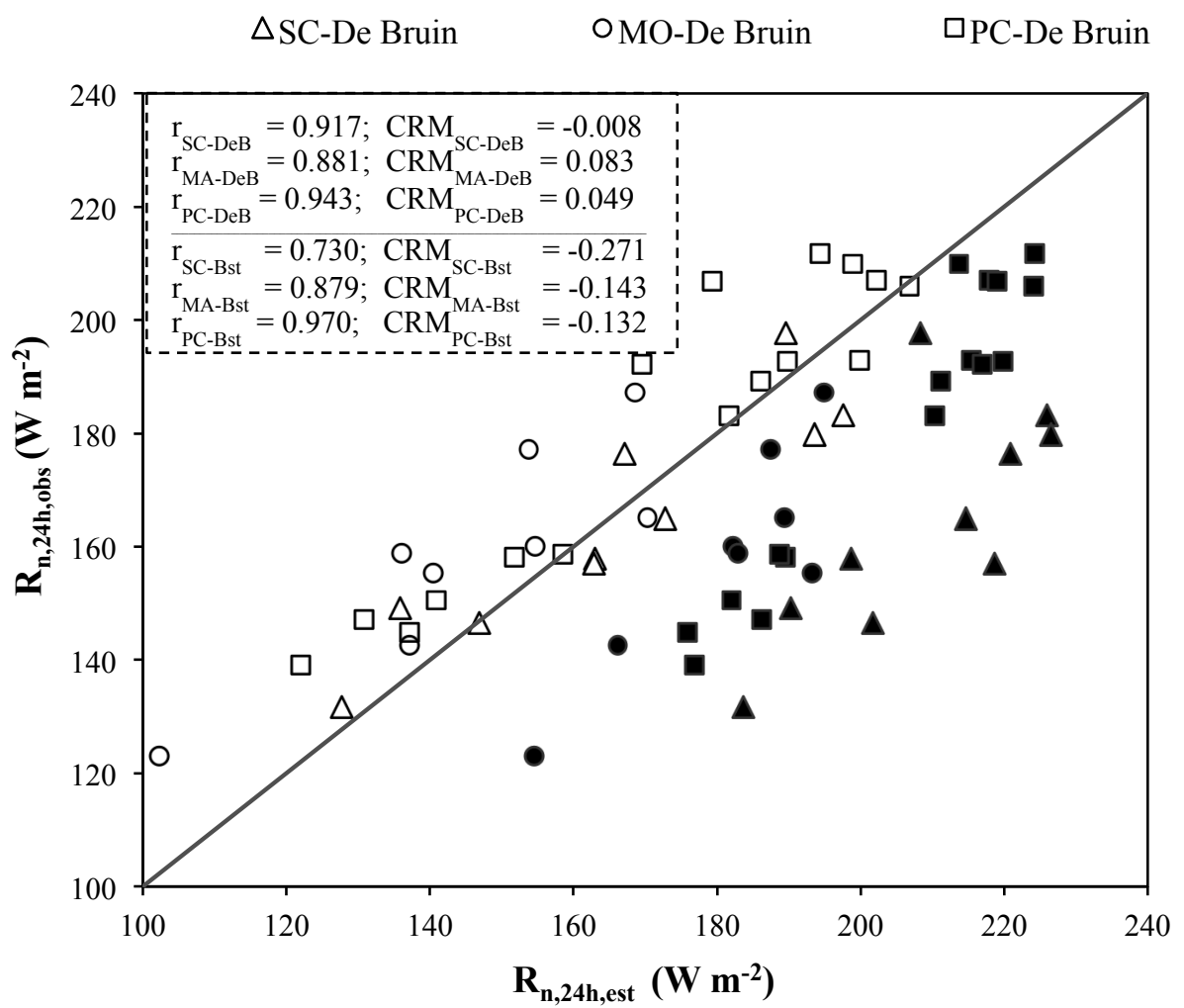

Figure 5. Representation of $\mathrm{R}_{\mathrm{n}, 24, \mathrm{est}}\left(\mathrm{R}_{\mathrm{n}, 24}\right.$ estimated, $\left.\mathrm{W} \mathrm{m}^{-2}\right)$ by Eq. $14-\mathrm{R}_{\mathrm{n}, 24, \text { DeB }}$ and Eq. 15 $\mathrm{R}_{\mathrm{n}, 24, \mathrm{Bst}}$ compared with integrated observed values of net radiation for the three vegetated surfaces: sugarcane (SC), mango orchard (MO) and pristine caatinga (PC) $-\mathrm{R}_{\mathrm{n}, 24, \mathrm{obs}}$

The data of $R_{n, 24, B s t}$ overestimate $R_{n, 24, \text { obs }}$ by disregarding the negative values of $R_{n}$, occurring throughout the night and for almost an hour after sunrise and before sunset. It is very important to note that in applications where $\mathrm{R}_{\mathrm{n}, 24}$ is required to determine the evapotranspiration by remote sensing, it would be advisable not to use the Bisht method, since it overestimates the $\mathrm{R}_{\mathrm{n}, 24}$ by more than $100 \%$. However, despite the poor performance of the sinusoidal model (Eq. 15) on a daily basis, it presents good agreement with instantaneous $R_{n}(t)$ values when $R_{n}$ is positive (Fig. 6). 


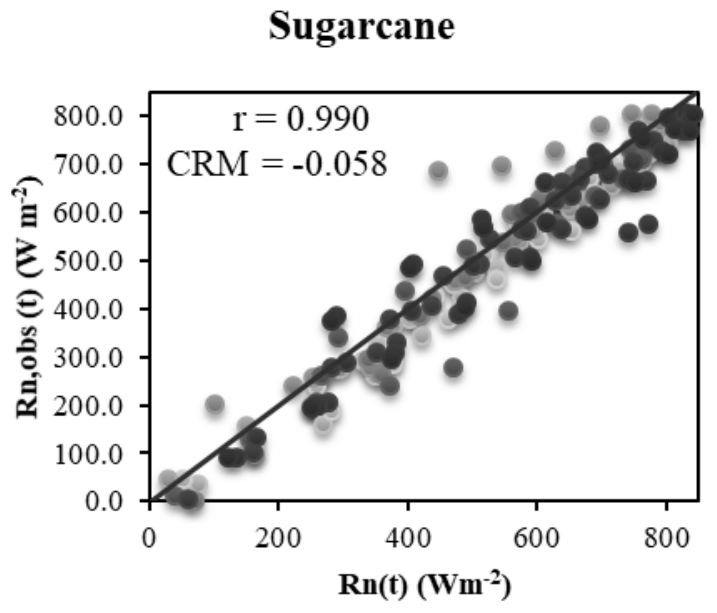

• 1502013 •2462013 • 2782013 •009 2014 • 2172014

• 2652014 • $2362015 \bullet 2522015 \bullet 3002015 \bullet 3162015$

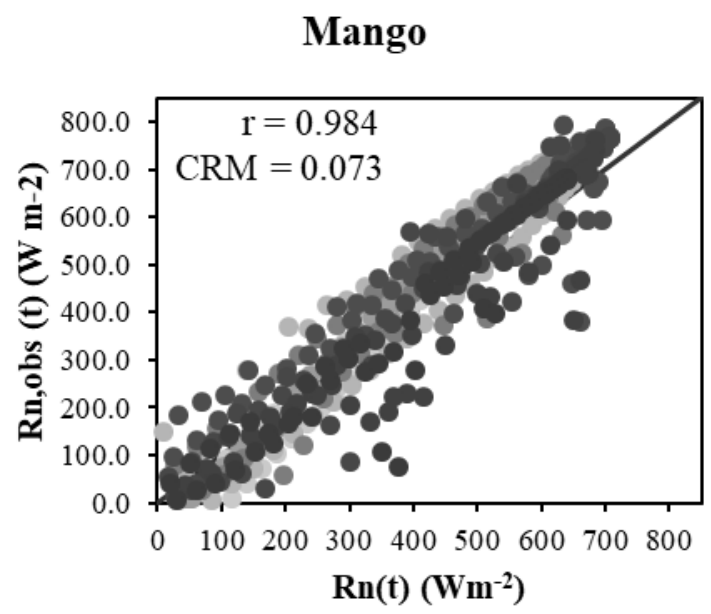

• 1612017 •2892017•2282018•260 2018

$\bullet 0392019 \bullet 0712019 \bullet 1032019 \bullet 1192019$

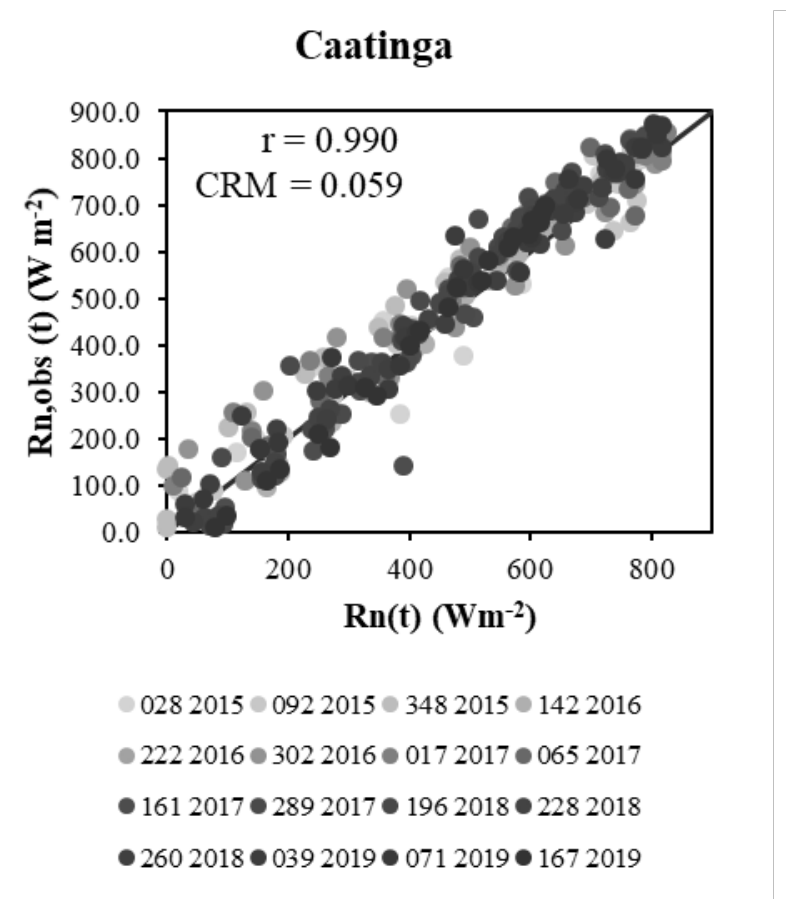

Figure 6. Performance of sinusoidal model for $R_{n}(t)$ (Eq. 2 ) as compared with $R_{n, \text { obs }}(t)$ over a sugarcane field (SC), mango orchard (MO) and pristine caatinga (PC). The legend indicates the day number and year of points on the plots (for each day the values were computed at the same interval as the measurements were conducted at the micrometeorological towers -10 minutes for the MO and 30 minutes for $\mathrm{SC}$ and $\mathrm{PC})$. 
Land use change, as a result of the replacement of primary vegetation by grassland, agricultural

400

401

402

403

404

405

406

407

408

409

410

411

412

413

414

415

416

417

418

419

420

421

422

423

424

425

426

crops, and urban occupation, can substantially affect the exchange of heat and mass in the soil-plantatmosphere system. Fig. 7 shows the spatial distribution of albedo, NDVI, land surface temperatureLST $\left({ }^{\circ} \mathrm{C}\right)$, and surface emissivity $-\varepsilon_{0}$ obtained from remote sensing on January 9 , 2014. In these maps there is an obvious presence of the São Francisco riverbed crossing the study area from west to northeast; it stands out due to low albedo values (water bodies generally have values of $0.05-0.08$ ) and low LST values $\left(<20^{\circ} \mathrm{C}\right.$, much lower than the air temperature). Irrigated and urban areas show considerably different pixel values and patterns of NDVI, LST, and $\varepsilon_{0}$.

The urban areas of the municipality of Petrolina and Juazeiro cities have high albedo values, which means greater reflection of downwelling shortwave radiation, and the LST is high, which increases the emitted longwave radiation. Consequently, the instantaneous net radiation over urban areas (as calculated using Eq. 1) is smaller than that over the vegetated surfaces, especially the irrigated plots, where albedo and LST are much lower.

Selected images, as shown in Fig. 8, presented $\mathrm{R}_{\mathrm{n}, \mathrm{over}}\left(\mathrm{W} \mathrm{m}^{-2}\right)$ for: a) January 9, 2014 - DOY 9; b) September 22, 2014 - DOY 265; c) August 24, 2015 - DOY 236; and November 12, 2015 - DOY 316. The values of $R_{n, \text { over }}$ obtained over the entire study area are highest for January 9, 2014 (Fig. 7-d and 9-a), ranging from $260.8 \mathrm{~W} \mathrm{~m}^{-2}$ to $722.0 \mathrm{~W} \mathrm{~m}^{-2}$. On August 24, 2015 (Fig. 8-c) the values are the lowest, although the patterns are basically the same as those shown in the other maps, as a consequence of the lower downwelling shortwave radiation $-\mathrm{R}_{\mathrm{sw}}$ on this day, caused by low $\tau_{\mathrm{sw}}$ (related to atmospheric conditions), $\mathrm{dr}$ (due to higher earth-sun distance) and $\cos (\mathrm{Z})$ (due to seasonality), (see Tables S2 and S3).

For reasons explained previously the river exhibits the highest values of $\mathrm{R}_{\mathrm{n}, \mathrm{over}}$, followed by the caatinga vegetation and the irrigated plots, particularly those located to the southeast of the São Francisco river. The net shortwave radiation for the caatinga vegetation is generally higher than in the agricultural areas, due to its lower albedo; however, the longwave radiation emitted by caatinga is also expected to be higher (higher LST). The caatinga often presents low LAI (except in the wet season) (Miranda et al., 2020), which means a lower emissivity (Fig. 7d), due to the fact that the emissivity of soil is generally lower than that of leaves; therefore, despite the fact that the Caatinga has high values 
of $\mathrm{LST}^{4}$, it has a lower emissivity than the irrigated areas. This combination makes the caatinga $\mathrm{R}_{\mathrm{n}}$ similar to that of agricultural land during large parts of the year (Carvalho et al., 2018a).

Although $R_{n}$ of the irrigated areas is similar to that of the caatinga areas, the irrigated areas use a large part of this energy for transpiration (Carvalho et al., 2018; Teixeira et al., 2008), as it has higher soil moisture contents, which leads to a lower LST which may impact the local climate over these areas. It is very likely that these crops are using energy advected from nearby drier areas (e.g. pasture or thin caatinga with exposed soil, with much higher sensible heat fluxes) (Oliveira \& Leitao, 2000), causing the surface temperatures of the irrigated areas to decrease even more.

It can be observed that in the areas dominated by pasture and urban infrastructure, the values of LST and albedo are higher, and NDVI and $\mathrm{R}_{\mathrm{n}, \mathrm{vver}}$ are lower, than those calculated for caatinga and crops. For pasture, this may be due to lower plant density, which results in more dry exposed soil, with higher albedos and lower rates of cooling evaporative fluxes, which will increase LST. Another, related, factor contributing to high rangeland LSTs is the fact that grasses have shallow roots and can, therefore only access near-surface soil moisture, which is more rapidly depleted.

Bezerra et al. (2013) showed that rural areas presented air temperatures that were lower (difference on the air minimum temperature recorded of $5.9^{\circ} \mathrm{C}$ and for the air maximum temperature of $2.3{ }^{\circ} \mathrm{C}$ ) than the temperature measured for the city of Petrolina. It is a fact that the caatinga vegetation can present various physiognomies (from woodlands to sparsely distributed thorny shrubs; Silva et al., 2017), and each of these has a different vegetation structure. The grazing that occurs at some Caatinga sites also impacts the vegetation density, and consequently its spatiotemporal dynamics, and related surface variables such as NDVI (Silveira et al., 2018), LST, albedo and emissivity. Ultimately, this will affect the micro- and regional climate and soil-land-surfaceatmosphere fluxes. 

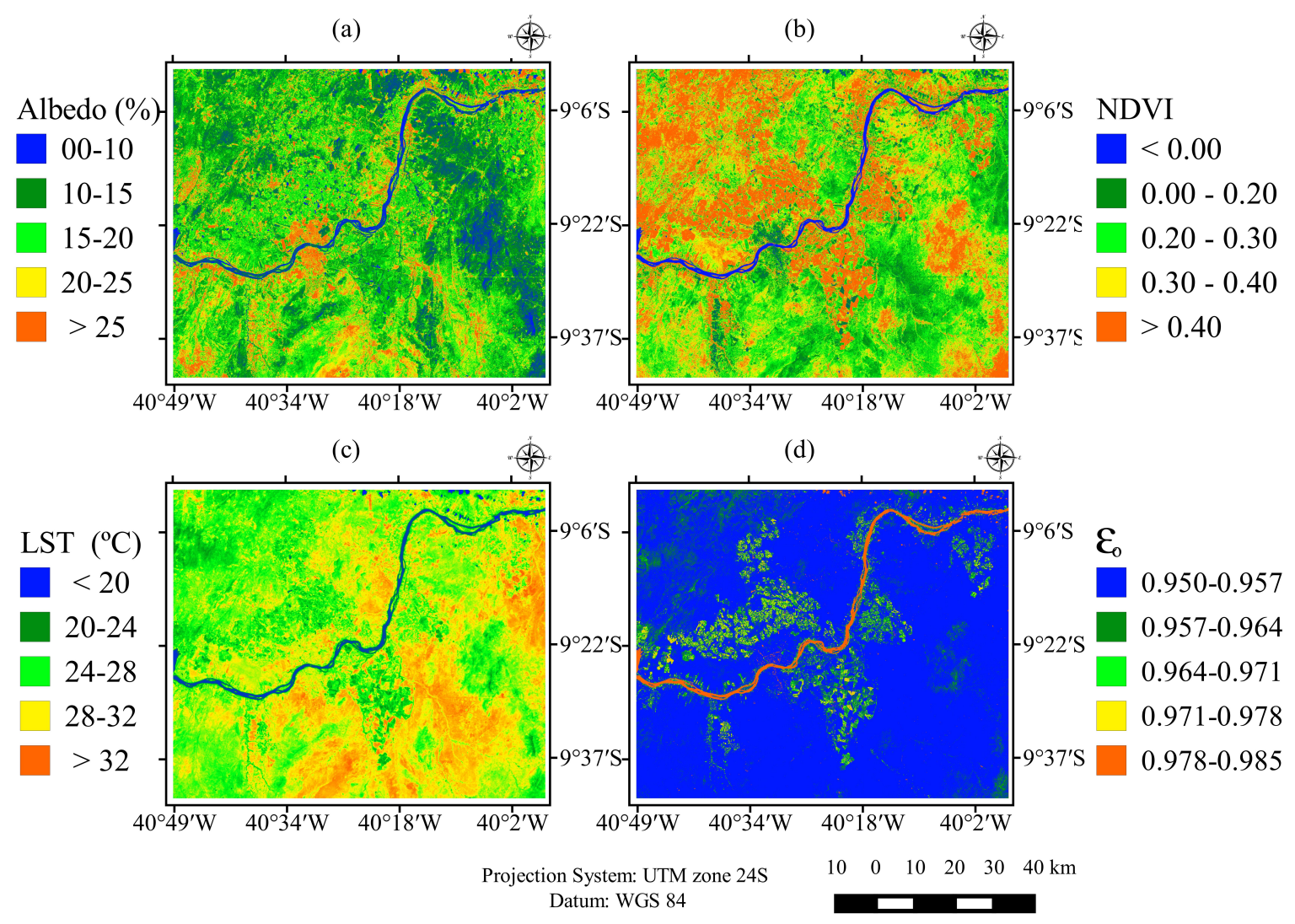

Figure 7. (a) Instantaneous albedo, (b) NDVI, (c) LST, and (d) $\varepsilon_{0}$ on January 9, 2014 - DOY 9.

In an oasis area, Bastiaanssen et al. (1998) reported $\mathrm{R}_{\mathrm{n}, \text { over }}$ values close to $600 \mathrm{~W} \mathrm{~m}^{-2}$ and smaller than $400 \mathrm{~W} \mathrm{~m}^{-2}$ for desert pixels in summer. At the Mogi-Guaçu watershed in southeast Brazil, a semi-humid region, Silva et al. (2015) recorded $R_{n}$ values, during 2005, similar to those observed in this study over urban and agricultural areas, despite the fact that climatic conditions were different. Bare soil $R_{n}$ values ranging between $310-430 \mathrm{~W} \mathrm{~m}^{-2}$ (between spring and summer) were detected in a semi-arid area of Brazil (Di Pace et al., 2008) and between $500-550 \mathrm{~W} \mathrm{~m}^{-2}$ (in summer) in a region with high advective effects (Chavez et al., 2007). However, it is important to consider that values of $\mathrm{R}_{\mathrm{n}}$ depend on the complex interactions within the soil-plant-atmosphere system, and on the local seasonal evolution and patterns of rainfall and downwelling radiation components, as well as on the highly dynamic nature of the crop management and irrigated agricultural activities taking place in this important area of agricultural production. 


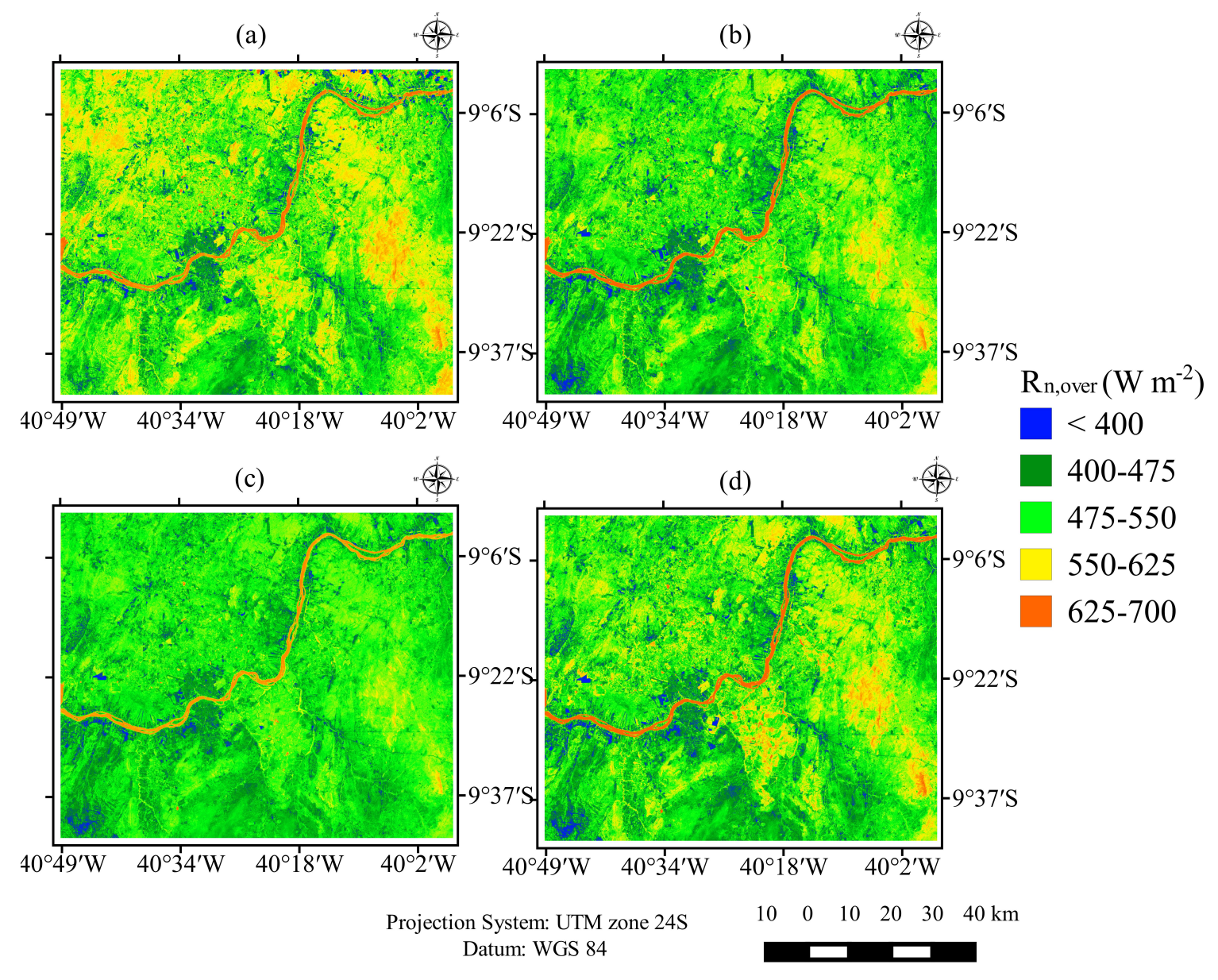

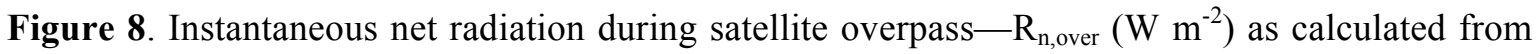
remote sensing information on: a) January 9, 2014; b) September 22, 2014; c) August 24, 2015 and d) November 12 .

\subsection{Estimates of daily net radiation}

In Fig. 9, maps of $R_{n, 24, \text { DeB }}$ values for June 2, 2014 (DOY = 153) and November 12, 2015 (DOY = 316) are shown. The $R_{n, 24, \text { DeB }}$ patterns are similar to those obtained for $R_{n, \text { over }}$ (see Fig. 8). The seasonality of $R_{n}$ can be observed in this figure; in June most of the $R_{n, 24, \text { DeB }}$ values were between 60 and $160 \mathrm{~W} \mathrm{~m}^{-2}$ (close to the winter solstice, with $\mathrm{R}_{\mathrm{sw}, 24}$ of $245.1 \mathrm{~W} \mathrm{~m}^{-2}$ and $\tau_{\mathrm{sw}, 24}$ of 0.709 , see Table S3), whereas a substantial increase in $R_{n}$ was found for November, resulting in values between 80 and $200 \mathrm{~W} \mathrm{~m}^{-2}$ (close to the summer solstice, with $\mathrm{R}_{\mathrm{sw}, 24}$ of $326.7 \mathrm{~W} \mathrm{~m}^{-2}$ and $\tau_{\mathrm{sw}, 24}$ of 0.721 , see Table $\mathrm{S} 3$ ). 

$\mathrm{m}^{-2}$ (on the same dates) for bare soil.

473

(a)

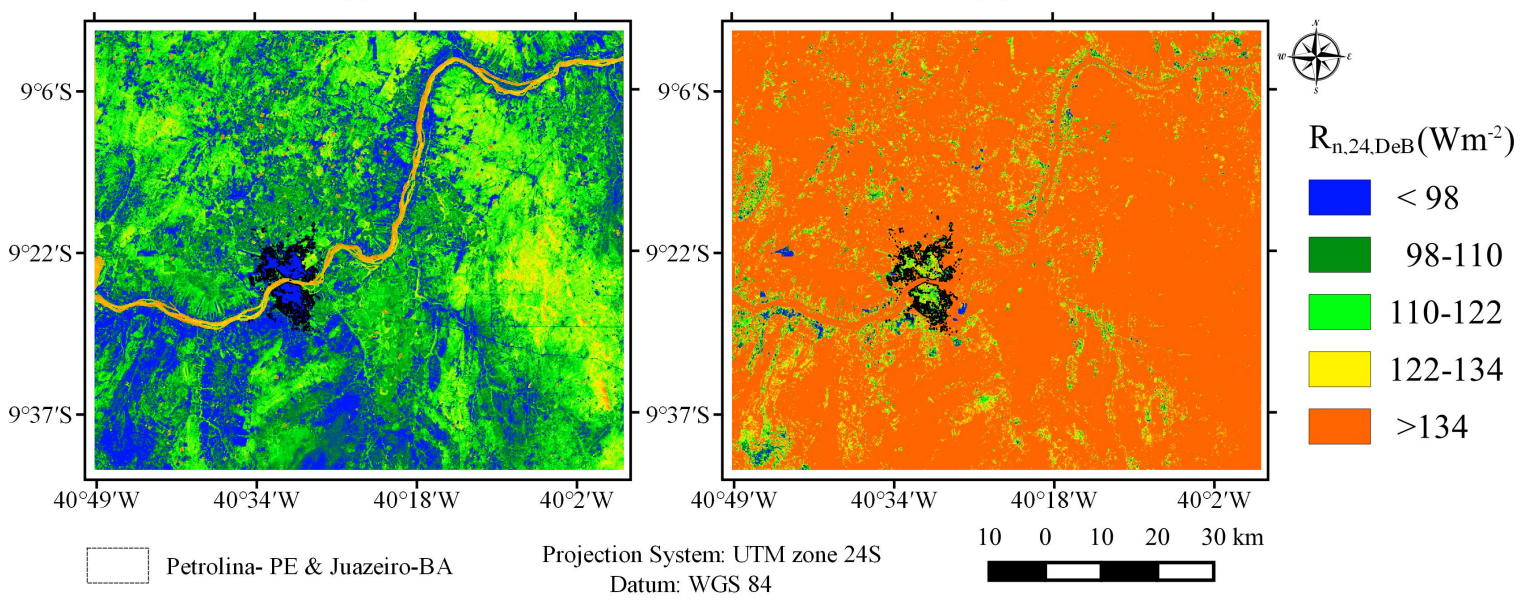

Figure 9. Daily net radiation $-\mathrm{R}_{\mathrm{n}, 24, \mathrm{DeB}}\left(\mathrm{W} \mathrm{m}^{-2}\right.$ ) on: a) June 2, 2014 (DOY 153) and b) November 12, 2015 (DOY 316).

\subsection{The effect of land use changes on net radiation}

Fig. 10 presents the box-plot diagrams for the same variables as presented in Fig. 7, NDVI, LST

$(\mathrm{K})$, albedo, surface emissivity, $\varepsilon_{0}$, and for $\mathrm{R}_{\mathrm{n}, \mathrm{over}}\left(\mathrm{W} \mathrm{m}^{-2}\right)$, generated from the pixel data for the four contrasting land-cover types (100 random points extracted for each land-cover type, see Section 2.1). The irrigated pixels have a higher NDVI and $\varepsilon_{0}$ and lower LST than the other types, while $\mathrm{R}_{\mathrm{n}, \mathrm{over}}$ is similar and albedo is slightly higher than the values found for caatinga (as mentioned above). The variability (as indicated by the interquartile range) of NDVI, $\varepsilon_{0}$ and LST of irrigated areas is much higher than that calculated for other areas, indicating that the existence of different crops and their different cultivation phases, result in greater spatiotemporal variability than the variability caused by seasonality for pasture and Caatinga.

Figure 10 shows that the highest $R_{n}$ values were mostly found for irrigated agriculture and the caatinga. We would expect high values for the irrigated agriculture, because their low LST values and low albedo values result in large values of net longwave and net shortwave radiation. However, high 
$R_{n}$ values are not so obvious for the caatinga because it has high surface temperatures, hence in principle should have high longwave upwelling radiation. However, its relatively low value of surface emissivity, $\varepsilon_{0}$, tempers the losses resulting from longwave upwelling radiation to a certain degree. Note also, that the albedo values for caatinga are the lowest among all land cover types (including crops), which results in larger values of net shortwave for this surface cover. Pasture has the lowest $R_{n}$ values among the vegetated land cover types. This is caused by the fact that its LSTs are even higher than those for caatinga and its $\varepsilon_{0}$ is comparable to that of caatinga so that its net longwave radiation is the lowest (i.e. more negative than for the other surface types). At the same time, the albedo for pasture is considerably larger than that of caatinga, causing net shortwave radiation also to be low for pasture. Interestingly, the LST values for urban areas are comparable to those of caatinga and pasture, in some cases they are even lower; also, urban emissivities are comparable or lower than those of caatinga and pasture, so that urban net longwave radiation is higher or comparable to that of caatinga and pasture. Yet, their $R_{n}$ values are the lowest of all surface types, because of their high albedo. be slightly higher and $\mathrm{R}_{\mathrm{n}}$ lower. If it is changed to urban areas, albedo will increase, but LST will in fact be similar or slightly lower, and $\mathrm{R}_{\mathrm{n}}$ will be lower. If it is turned to irrigated crops, albedo will be slightly higher, LST 3-5 degrees lower, yet $\mathrm{R}_{\mathrm{n}}$ will remain similar to the values calculated for PC, as a result of the considerably lower surface emissivity for caatinga. Fig. S1 (in the supplementary material) illustrates the impact on the net radiation, discussed above, caused by land use change over the study period, for two subsets of the study area.

These data illustrate that land use substantially affects net radiation, via its upwelling shortwave and longwave components. This will affect the available energy (net radiation minus storage of heat in the vegetation and soil) and possibly aerodynamic roughness parameters (e.g. crops will have a 511 lower roughness length and displacement height), which will affect the exchange of water vapour and heat between the land surface and the atmosphere (data not shown). These combined effects will have an impact on the climate locally, via land-surface atmosphere feedbacks, if the size of the changed area is relatively large and fairly homogeneous, as in the case for caatinga in this study. 
Land-cover type: 帛 Agriculture 帛 Caatinga 帛 Pasture 帛 Urban

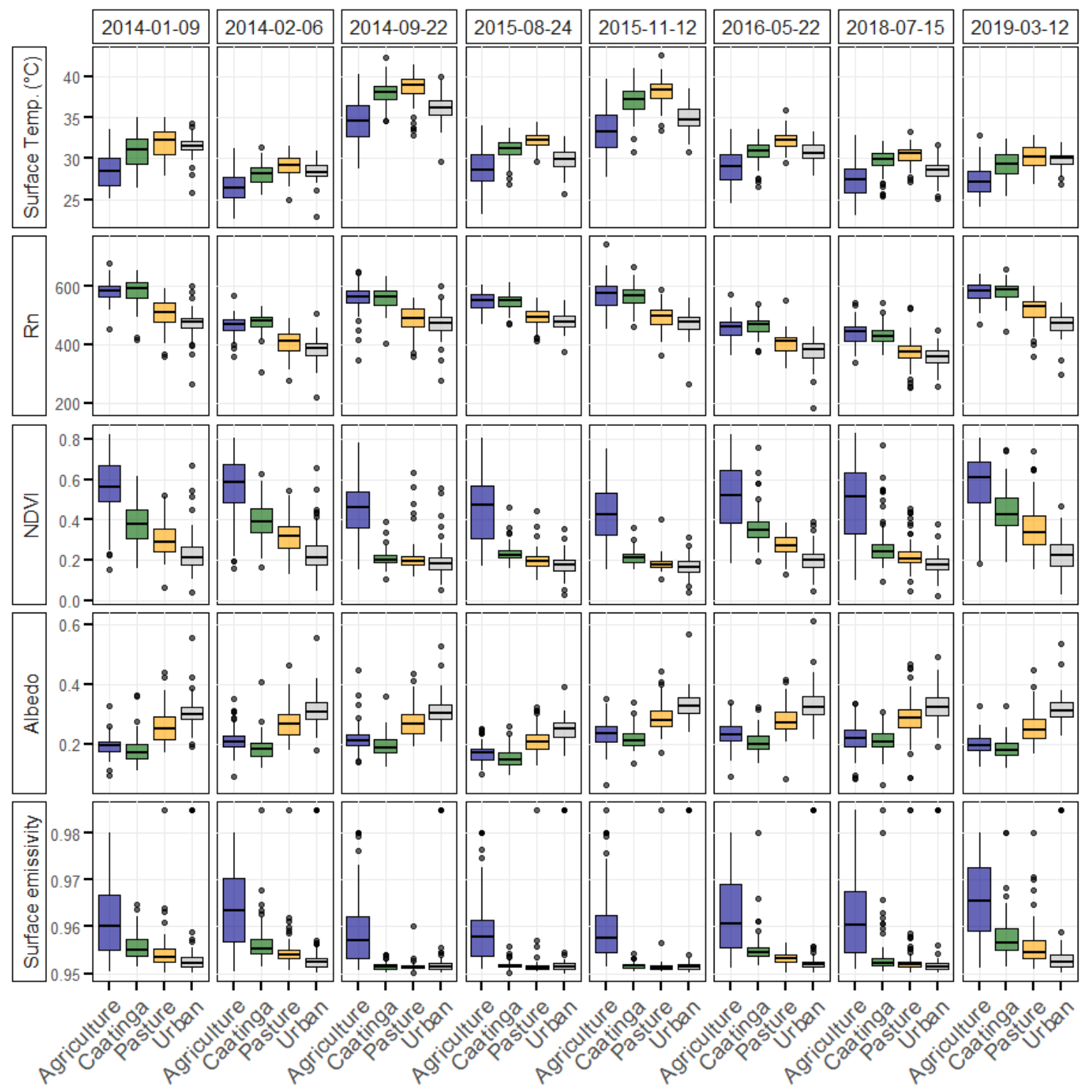

Figure 10. Box-plot diagrams of the LST $(\mathrm{K}), \mathrm{R}_{\mathrm{n}, \mathrm{over}}\left(\mathrm{W} \mathrm{m}^{-2}\right)$, NDVI, , Albedo and surface emissivity for agriculture (irrigated), urban infrastructure, caatinga vegetation and pasture.

\section{Conclusions}

The effects that climate and seasonality have on the downwelling components and that land use

has on the upwelling components of the surface radiation balance were evaluated for a semiarid area in Brazil (within the Brazilian Caatinga), consisting of a mosaic of remaining areas of pristine natural 
seasonally dry forest vegetation (caatinga), irrigated agriculture and semi-natural rangeland. We used

522

523

524

525

526

527

528

529

530

531

532

533

534

535

536

537

538

539

540

541

542

543

544

545

546

547 two models to calculate downwelling shortwave radiation, and ten models of clear-sky atmospheric emissivity to calculate downwelling longwave radiation following the Stefan Boltzmann's equation. We used Landsat 8 satellite images to derive the required biophysical variables, such as albedo and land surface temperature, and climate variables measured at a nearby weather station were used to calculate longwave downwelling radiation. The selected shortwave and longwave models performed well when compared against in-situ SONDA station measurements as evaluated using the MAE, MRE, and RMSE metrics.

The spatial patterns obtained show that the land-use, in particular the caatinga vegetation cover, substantially affects those components of the net radiation that depend on the type and state of the land surface cover, such as reflected shortwave radiation and emitted longwave radiation. It is important that reliable equations are employed to calculate the separate components of net radiation, so that subsequent estimates of sensible and latent heat flux are more accurate.

In this context, we show that the sinusoidal model (Bisht, 2005), used for determination of the daily net radiation from instantaneous values of $R_{n}$ determined from remote sensing, considerably overestimates daily net radiation estimates, $\mathrm{R}_{\mathrm{n}, 24}$, as a consequence of the fact that this model does not consider the negative values of $\mathrm{R}_{\mathrm{n}}$ that occur throughout the night period and part of the daytime period. On the other hand, the De Bruin model, that only uses remote sensing-based values of net shortwave radiation (and an empirical term, derived from weather data, to represent net longwave radiation), performed very satisfactorily.

In the rangeland, the albedo, land surface temperature, LST, and hence the upwelling shortwave and longwave radiation components, had greater values than in the pristine caatinga, which contributes to a reduction in the net radiation at the surface, and most likely an increase in sensible heat flux via higher LSTs (data not shown). In the urban areas, the LST and the surface emissivity are comparable to those found for the caatinga and pasture values, but the albedo values are the highest of all surface types, which resulted in the lowest net shortwave radiation and consequently, the lowest $\mathrm{R}_{\mathrm{n}}$. The albedo in the irrigated agricultural crops is $0.01-0.03$ greater than in the pristine caatinga, and 
the LST is $3-5$ degrees smaller; yet, $R_{n}$ for these two land uses is similar, as a result of considerably lower surface emissivity for caatinga.

We provide evidence that when in-situ data of net radiation are not available, remote sensing data, combined with more readily available data such as air temperature, pressure and humidity, can be used to derive reliable spatiotemporal estimates of $R_{n}$ that can identify environmental and anthropogenic, and short-term as well as long-term, impacts on the land surface radiation balance, and ultimately on the energy balance. We would like to emphasize that remote sensing studies, such as the one presented here, are crucial in the determination of the available energy for the turbulent fluxes (e.g. evapotranspiration, ET) between the surface and the atmosphere, on the regional scale. Reliable estimation of ET is of great importance in the context of irrigation planning and wider water management, again underlining the need for reliable and accurate data.

\section{Funding:}

This research was partly supported by the National Council for Scientific and Technologic Development - CNPq and Coordination for the Improvement of Higher Education Personnel - CAPES of Brazil government. MSBM, AV and RLBN acknowledge support from the UK/Brazil Nordeste project, funded jointly through the UK Natural Environment Research Council (NE/N012488/1 UoR and NE/N012526/1 ICL) and FAPESP (São Paulo Research Foundation) (FAPESP 2015/50488-5), and MSBM thank to Fundação de Amparo à Ciência e Tecnologia do Estado de Pernambuco for funding this through the Project FACEPE APQ 0062-1.07/15 (Caatinga-FLUX).

\section{Declarations of interest:}

None.

\section{Appendix A. Supplementary data:}

Supplementary data to this article can be found online at...

\section{References}


574 Alados, I., Foyo-Moreno, I., Alados-Arboledas, L. (2012). Estimation of downwelling longwave irradiance under all-sky conditions. Int. J. Climatol. 32 (5), 781-793. https://doi.org/10.1002/joc.2307.

Allen, R. G. (1996). Assessing integrity of weather data for use in reference evapotranspiration estimation. J. Irrig. Drain. Eng., 122(2), 97-106. https://doi.org/10.1061/(ASCE)07339437(1996)122:2(97)

Allen, R., Irmak, A., Trezza, R., Hendrickx, J. M. H., Bastiaanssen, W., \& Kjaersgaard, J. (2011). Satellite-based ET estimation in agriculture using SEBAL and METRIC. Hydrological Processes, 25, 4011-4027. http://dx.doi.org/10.1002/hyp.8408

Allen, R. G., Tasumi, M., Trezza, R. (2007). Satellite-based energy balance for mapping evapotranspiration with internalized calibration (METRIC) - Model. J. Irrig. Drain. Eng., 133, 380-394. https://doi.org/10.1061/(ASCE)0733-9437(2007)133:4(380).

ASCE-EWRI. (2005). The ASCE standardized reference evapotranspiration equation. ASCE-EWRI Standardization of Reference Evapotranspiration Task Committe Rep., ASCE Reston, Va. https://doi.org/10.1061/40499(2000)126

Bastiaanssen, W. G. M. (2000). SEBAL-based sensible and latent heat fluxes in the irrigated Gediz Basin, Turkey. J. Hydrol., 229, 87-100. https://doi.org/10.1016/S0022-1694(99)00202-4.

Bastiaanssen, W. G. M., Menenti, M., Feddes, R. A., Holtslag, A. A. M. (1998). A remote sensing surface energy balance algorithm for land (SEBAL). 1: Formulation. J. Hydrol., 212-213, 98212. https://doi.org/10.1016/S0022-1694(98)00253-4.

Bastiaanssen, W. G. M., Noordman, E. J. M., Pelgrum, H., Davids, G., Thoreson, B. P., Allen, R.G. (2005). SEBAL model with remotely sensed data to improve water resources management under actual field conditions. J. Irrig. Drain. Eng., 131(1), 85-93. https://doi.org/10.1061/(ASCE)0733-9437(2005)131:1(85). 
Bezerra, P. T. C., Leitão, M. M. V. B. R., Azevedo, P. V. (2013). Ilhas de Calor e Desconforto Térmico no Semiárido Brasileiro: Um Estudo de Caso na cidade de Petrolina-PE. Rev. Bras. Geogr. Fís., 6, 427-441.

Bisht, G., Bras, R. L. (2010). Estimation of net radiation from the MODIS data under all sky conditions: Southern Great Plains case study. Remote Sens. Environ., 114, 1522-1534. https://doi.org/10.1016/j.rse.2010.02.007.

Bisht, G., Bras, R. L. (2011). Estimation of net radiation from the Moderate Resolution Imaging Spectroradiometer over the continental United States. IEEE Trans. Geosci. Remote Sens., 49, 2448-2462. http://dx.doi.org/10.1109/TGRS.2010.2096227.

Bisht, G., Venturini, V., Islam, S., Jiang, L. (2005). Estimation of the net radiation using MODIS (Moderate Resolution Imaging Spectroradiometer) data for clear-sky days. Remote Sens. Environ., 97, 52-67. https://doi.org/10.1016/j.rse.2005.03.014.

Brutsaert, W. (1975). On a derivable formula for long-wave radiation from clear skies. Water Resour. Res., 11, 742-744. https://doi.org/10.1029/WR011i005p00742.

Carvalho, H. F. S., Moura, M. S. B., Silva, T.G.F. (2018). Fluxos de radiação e energia em caatinga preservada e cana-de-açúcar no Semiárido. Rev. Bras. Meteorol., 33, 452-458. http://dx.doi.org/10.1590/0102-7786333005.

Carmona, F., Rivas, R., \& Caselles, V. (2014). Estimation of daytime downwelling longwave radiation under clear and cloudy skies conditions over a sub-humid region. Theoretical and Applied Climatology, 115, 281-295. http://dx.doi.org/10.1007/s00704-013-0891-3.

Chavez, J. L., Gowda, P. H., Howell, T. A., Marek, T. H. and New, L. L. (2007). Evapotranspiration mapping using METRICTM for a region with highly advective conditions. In 2007 ASABE Annual International Meeting, Technical Papers. Vol. 4. https://doi.org/10.13031/2013.23414. 
Choi, M. (2013). Parameterizing daytime downwelling longwave radiation in two Korean regional flux monitoring network sites. J. Hydrol. 476, 257-264. https://doi.org/10.1016/j.jhydrol.2012.10.041

CNUC/MMA. Unidades de accessed on 24 Apr 2018).

Cunha, J., Nóbrega, R., Rufino, I., Erasmi, S., Galvão, C., Valente, F. (2020). Surface albedo as a 630 proxy for land-cover clearing in seasonally dry forests: evidence from the Brazilian Caatinga. Remote Sens. Environ. https://doi.org/10.1016/j.rse.2019.111250.

Driemel, A., Augustine, J., Behrens, K., Colle, S., Cox, C., Cuevas-Agulló, E., Denn, F. M., Duprat, T., Fukuda, M., Grobe, H., Haeffelin, M., Hodges, G., Hyett, N., Ijima, O., Kallis, A., Knap, W., Kustov, V., Long, C. N., Longenecker, D., Lupi, A., Maturilli, M., Mimouni, M., Ntsangwane, L., Ogihara, H., Olano, X., Olefs, M., Omori, M., Passamani, L., Pereira, E. B., Schmithüsen, H., Schumacher, S., Sieger, R., Tamlyn, J., Vogt, R., Vuilleumier, L., Xia, X., Ohmura, A., and König-Langlo, G. (2018). Baseline Surface Radiation Network (BSRN): structure and data description (1992-2017), Earth Syst. Sci. Data, 10, 1491-1501, https://doi.org/10.5194/essd-10-1491-2018.

De Bruin, H. A. R. (1987). From Penman to Makkink. In: Hooghart, J. C. (Ed.), Proceedings and information: TNO Commitee on Hydrological. Gravennhage, The Netherlands. 39, 5-31. radiação com imagens Landsat 5 e modelo de elevação digital. Rev. Bras. Eng. Agríc. Ambient., 12, 385-392. http://dx.doi.org/10.1590/S1415-43662008000400009. 
Duarte, H. F., Dias, N. L., Maggiotto, S. R. (2006). Assessing daytime downwelling longwave radiation estimates for clear and cloudy skies in Southern Brazil. Agric. For. Meteorol., 139, 171-181. https://doi.org/10.1016/j.agrformet.2006.06.008.

Elnmer, A., Khadr, M., Kanae, S., \& Tawfik, A. (2019). Mapping daily and seasonally evapotranspiration using remote sensing techniques over the Nile delta. Agric. Water Manage., $213,682-692$.

Garrison, J.D., Adler, G.P. (1990). Estimation of precipitable water over the United States for application to the division of solar radiation into its direct and diffuse components. Sol. Energy 44, 225-241. https://doi.org/10.1016/0038-092X(90)90151-2.

Hoagland, S.J., Beier, P., Lee, D. (2018). Using MODIS NDVI phenoclasses and phenoclusters to characterize wildlife habitat: Mexican spotted owl as a case study. For. Ecol. Manage. 412, 8093. https://doi.org/10.1016/j.foreco.2017.12.017.

IBGE. Estados: População, Instituto Brasileiro de Geografia, Rio de Janeiro: $<$ http://censo2010.ibge.gov.br/apps/atlas/> (last accessed on July 2018).

Idso, S. B. (1981). A set of equations for full spectrum and 8 to $14 \mu \mathrm{m}$ and 10.5 to $12.5 \mu \mathrm{m}$ thermal radiation from cloudless skies. Water Resour. Res., 17, 295-304. https://doi.org/10.1029/WR017i002p00295.

Idso, S. B., Jackson, R. D. (1969). Thermal radiation from the atmosphere. J. Geohys. Res., 74, 53975403. https://doi.org/10.1029/JC074i023p05397.

INMET. Instituto Nacional de Meteorologia. NORMAIS CLIMATOLÓGICAS DO BRASIL. Available at $<$ http://www.inmet.gov.br/portal/index.php?r=clima/normaisclimatologicas $>$ (last accessed on 30 Sep 2018).

Jensen, M. E., Allen, R. G. (2016). Evaporation, Evapotranspiration, and Irrigation Water Requirements, ASCE Manuals and Reports on Engineering Practice No. 70. 2nd ed. American Society of Civil Engineers, Reston, VA. 
Jin, Y., Randerson, J. T., Goulden, M. L. (2011). Continental-scale net radiation and evapotranspiration estimated using MODIS satellite observations. Remote Sens. Environ., 115, 2302-2319. https://doi.org/10.1016/j.rse.2011.04.031.

Kilic, A., Allen, R., Trezza, R., Ratcliffe, I., Kamble, B., Robison, C., Ozturk, D. (2016). Sensitivity of evapotranspiration retrievals from the METRIC processing algorithm to improved radiometric resolution of Landsat 8 thermal data and to calibration bias in Landsat 7 and 8 surface temperature. Remote Sens. Environ., 185, 198-209. https://doi.org/10.1016/j.rse.2016.07.011.

Kruk, N. S., Vendrame, I. F., Rocha, H. R, Chou, S. C., Cabral, O. (2010). Downwelling longwave radiation estimates for clear and all-sky conditions in the Sertãozinho region of São Paulo, Brazil. Theor. Appl. Climatol., 99, 115-123. http://dx.doi.org/10.1007/s00704-010-0347-y.

Kvalevag, M. M., Myhre, G., Bonan, G., Levis, S. (2010). Anthropogenic landcover changes in a GCM with surface albedo changes based on MODIS data. Int. J. Climatol., 30, 2105-2117. https://doi.org/10.1002/joc.2012.

Li, Z., Wang, Z., Liu, X., Fath, B. D., Liu, X., Xu, Y., Hutjes, R., Kroeze, C. (2019). Causal relationship in the interaction between land cover change and underlying surface climate in the grassland ecosystems in China. Sci. Total Environ., 647, 1080-1087. doi:10.1016/j.scitotenv.2018.07.401.

Lin, J., Liu, X., Li, K., Li, X. (2014). A maximum entropy method to extract urban land by combining MODIS reflectance, MODIS NDVI, and DMSP-OLS data. Int. J. Remote Sens. 35, 6708-6727. https://doi.org/10.1080/01431161.2014.960623.

Liu, Z., Liu, Y., Baig, M. H. A. (2019). Biophysical effect of conversion from croplands to grasslands in water-limited temperate regions of China. Sci. Total Environ., 648, 315-324. https://doi.org/10.1016/j.scitotenv.2018.08.128 
Markham, B. L., Barker, J. L. (1986). Landsat MSS and TM post-calibration dynamic ranges, exoatmospheric reflectances and at satellite temperatures. EOSAT Landsat Technical Notes 1:3-8, Earth Observation Satellite Company, Lanham, Md.

Marques, T. V., Mendes, K., Mutti, P., Medeiros, S., Silva, L., Perez-Marin, A. M., Campos, S., Lúcio, P. S., Lima, K., Reis, J., Ramos, T. M., Silva, D. F., Oliveira, C. P., Costa, G. B., Antonino, A. C. D., Menezes, R. S. C., Silva, C. M. S., Bezerra, B. G. (2020). Environmental and biophysical controls of evapotranspiration from Seasonally Dry Tropical Forests (Caatinga) in the Brazilian Semiarid. Agric. For. Meteorol. 287, 107957. https://doi.org/10.1016/j.agrformet.2020.107957.

Melo, E.C., Correia, M.F., Aragão, M.S. (2015). Expansão da Agricultura Irrigada e Mudanças nos Processos de Interação Superfície-Atmosfera: Um Estudo Numérico de Impacto Ambiental em Áreas de Caatinga. Rev. Bras. Geogr. Fís., 7, 960-968.

Miranda, R. Q., NÓBREGA, R. L. B., Moura, M. S. B., Raghavane, S., Galvíncio, J. D. (2020). Realistic and simplified models of plant and leaf area indices for a seasonally dry tropical forest. Int. J. Appl. Earth Obs., 85, 1-9.

Muñoz-Jiménez, J. C., Sobrino, J. A., Gillespie, A., Sabol, D., Gustafson, W. T. (2006). Improved land surface emissivities over agricultural areas using ASTER NDVI. Remote Sens. Environ., 103, 474-487. https://doi.org/10.1016/j.rse.2006.04.012.

Oliveira, G. M., Leitão, M. M. V. B. R. L. (2000). Estimativas de evapotranspiração e as consequências devido aos erros na determinação de saldo de radiação e efeitos advectivos. Rev. Bras. Eng. Agríc. Ambient., 4, 343-347.

Prata, A. J. (1996). A new long-wave formula for estimating downwelling clear-sky radiation at the surface. Q. J. R. Meteorol. Soc., 122, 1127-1151.https://doi.org/10.1002/qj.49712253306. 
Priestley, C. H. B., Taylor, R. J. (1972). On the assessment of surface heat flux and evaporation using large scale parameters. Mon. Wea. Rev. 100, 81-92. http://dx.doi.org/10.1175/15200493(1972)100<0081:OTAOSH>2.3.CO;2.

Projeto MapBiomas - Colection 3.1 from Annual Series of Brazilian coverage and land use maps. Available at: $<$ http://mapbiomas.org/>. (last accessed on 08 Jul 2019).

QGIS API. (2020). QGIS API Documentation. https://qgis.org/api/3.6/. Accessed Apr 2020.

Raynolds, M.K., Walker, D.A., Maier, H.A., 2006. NDVI patterns and phytomass distribution in the circumpolar Arctic. Remote Sens. Environ. 102, 3-4, 271-281. http://dx.doi.org/10.1016/j.rse.2006.02.016

Robinson, N.P.; Allred, B.W.; Jones, M.O.; Moreno, A.; Kimball, J.S.; Naugle, D.E.; Erickson, T.A.; Richardson, A.D. (2017). A Dynamic Landsat Derived Normalized Difference Vegetation Index (NDVI) Product for the Conterminous United States. Remote Sens., 9, 1-14. https://doi.org/10.3390/rs9080863.

Rouse, J.W, Haas, R.H., Scheel, J.A., and Deering, D.W. (1974). Monitoring Vegetation Systems in the Great Plains with ERTS. Proceedings, 3rd Earth Resource Technology Satellite (ERTS) $\begin{array}{llll}\text { Symposium, } & \text { vol. } & 1, & \text { p. }\end{array}$ https://ntrs.nasa.gov/archive/nasa/casi.ntrs.nasa.gov/19740022592.pdf

Ruhoff, A., Paz, A. R., Collischonn, W., Aragao, L., Rocha, H., \& Malhi, Y. (2012). A MODIS based energy balance to estimate evapotranspiration for clear-sky days in Brazilian tropical savannas. Rem. Sens., 4, 703-725. https://doi.org/10.3390/rs4030703.

Ryu, Y., Kang, S., Moon, S. K., Kim, J. (2008). Evaluation of land surface radiation balance derived from moderate resolution imaging spectroradiometer (MODIS) over complex terrain and heterogeneous landscape on clear sky days. Agric. For. Meteorol., 148, 1538-1552. https://doi.org/10.1016/j.agrformet.2008.05.008. 
Santos, C.A.C., Mariano, D.A., Nascimento, F.C.A., Dantas, F.R.C., Oliveira, G., Silva, M.T., Silva, L.L., Silva, B.B., Bezerra, B.G., Safa, B., Medeiros, S.S., Neale, C.M.U., 2020. Spatiotemporal patterns of energy exchange and evapotranspiration during an intense drought for drylands in Brazil. International Journal of Applied Earth Observation and Geoinformation 85, 101982. https://doi.org/10.1016/j.jag.2019. 101982

Santos, C. A. C., Silva, B. B. da, Rao, T. V. R., Satyamurti, P., Manzi, A. O. (2011). Downwelling longwave radiation estimates for clear-sky conditions over Northeast Brazil. Rev. Bras. Meteorol, 26, 443 - 450. http://dx.doi.org/10.1590/S0102-77862011000300010.

Silva, B. B. da, Braga, A. C., Braga, C. C. (2011). Balanço de radiação no perímetro irrigado São Gonçalo - PB mediante imagens orbitais. Rev. Caatinga, 24, Mossoró, 145-152.

Silva, B. B., Montenegro, S. M. G. L., Silva, V. d. P. R., Rocha, H. R., Galvincio, J. D., and Oliveira, L. M. M. (2015). Determination of instantaneous and daily net radiation from TM-Landsat 5 data in a subtropical watershed. J. Atmos. Sol-Terr. Phy., 135, 42-49. https://doi.org/10.1016/j.jastp.2015.09.020.

Silva, B.B. da, Braga, A. C., Braga, C. C., Oliveira, L. M. M. de, Montenegro, S.M.G.L., Barbosa Junior, B. (2016). Procedures for calculation of the albedo with OLI-Landsat 8 images: application to the Brazilian semiarid. Rev. Bras. Eng. Agríc. Ambient., 20, 3-8. http://dx.doi.org/10.1590/1807-1929/agriambi.v20n1p3-8.

Silva, J.M.C., Leal, I.R., Tabarelli, M. (2017). Caatinga: The Largest Tropical Dry Forest Region in South America. Springer International Publishing, Cham, Switzerland, https: //doi.org/10.1007/978-3-319-68339-3.

Silveira, H. L. F., Galvão, L. S., Sanches, I. D. A., Sá, I. B., Taura, T. A. (2018). Use of MSI/Sentinel2 and airborne LiDAR data for mapping vegetation and studying the relationships with soil attributes in the Brazilian semi-arid region. Int. J. Appl. Earth Obs. Geoinf, 73, 179-190. https://doi.org/10.1016/j.jag.2018.06.016 
Sugita, M., Brutsaert, W. H. (1993). Cloud effect in the estimation of instantaneous downwelling longwave radiation. Water Resour. Res., 29, 599-605. https://doi.org/10.1029/92WR02352.

Swinbank, W. C. (1963). Long-wave radiation in from clear skies. Q. J. R. Meteorol. Soc., 89, 339348. https://doi.org/10.1002/qj.49708938105.

Tang, B., Li, Z. L. (2008). Estimation of instantaneous net surface longwave radiation from MODIS cloud-free data. Remote Sens. Environ., $112, \quad 3482-3492$. https://doi.org/10.1016/j.rse.2008.04.004.

Tasumi, M. (2003). Progress in Operational Estimation of Regional Evapotranspiration Using Satellite Imagery. Ph.D. dissertation. University of Idaho, Moscow, ID.

Teixeira, A. H. C., Bastiaanssen, W. G. M., Ahmad, M. D., Bos, M. G. (2009). Reviewing SEBAL input parameters for assessing evapotranspiration and water productivity for the Low-Middle São Francisco River basin, Brazil - Part A: calibration and validation. Agric. For. Meteorol. 149, 462-476. https://doi.org/10.1016/j.agrformet.2008.09.016.

Teixeira, A. H. C., Bastiaanssen, W. G. M., Ahmad, M. D., Moura, M. S. B., Bos, M. G. (2008). Analysis of energy fluxes and vegetation-atmosphere parameters in irrigated and natural $\begin{array}{llllll}\text { ecosystems of semi-arid } \quad \text { Brazil. J. Hydrol., } & 362, \quad 110-127 .\end{array}$ https://doi.org/10.1016/j.jhydrol.2008.08.011

Trigo, I. F., de Bruin, H., Beyrich, F., Bosveld, F. C., Gavilán, P., Groh, J., López-Urrea, R. (2018). Validation of reference evapotranspiration from Meteosat Second Generation (MSG) $\begin{array}{lllll}\text { observations. } & \text { Agric. } & \text { Forest } & \text { Meteorol. } & 259,\end{array}$ https://doi.org/10.1016/j.agrformet.2018.05.008.

Urrutia, A. L., González-Gónzalez, C., Van Cauwelaert, E. M., Rosell, J. A., García Barrios, L., Benítez, M. (2020). Landscape heterogeneity of peasant-managed agricultural matrices. Agric. Ecosyst. Environ. 292, 106797. https://doi.org/10.1016/j.agee.2019.106797. 
USGS - United States Geological Survey. Landsat Update. Vol. 7 Issue 5, Available at: $<$ https://landsat.usgs.gov/sites/default/files/documents/about_LU_Vol_7_Issue_5.pdf $>$ (last accessed on $24 \mathrm{Jul} 2018$ ).

Vancoppenolle, M., Fichefet, T., Goosse, H., Bouillon, S., Madec, G., Morales Maqueda, M. A. (2009). Simulating the mass balance and salinity of Arctic and Antarctic sea ice. 1: Model description and validation. Ocean Modell. 27, 33-53. https://doi.org/10.1016/j.dsr2.2010.10.039.

Verhoef, A. and Campbell, C.L. (2005) Evaporation Measurement, Ch. 40. In: Encyclopedia of Hydrological Sciences Vol. 1. Editor: M.G. Anderson. John Wiley, Chichester, UK: 589-601.

Waldmann-Selsam, C., Balmori-de la Puente, A., Breunig, H., Balmori, A. (2016). Radiofrequency radiation injures trees around mobile phone base stations, Sci. Total Environ. 572, 554-569. https://doi:10.1016/j.scitotenv.2016.08.045.

Wang, W., Liang, S. (2009). Estimation of high-spatial resolution clear-sky longwave downwelling and net radiation over land surfaces from MODIS data. Remote Sens. Environ., 113, 745-754. https://doi.org/10.1016/j.rse.2008.12.004.

Wang, Y.P., Li, R., Min, Q, Fu, Y, Wang, Y., Zhong, L., and Fu, Y.-Y. (2019). A Three-source Satellite Algorithm for Retrieving All-sky Evapotranspiration Rate using Combined Optical and Microwave Vegetation Index at Twenty Asia Flux Sites, Remote Sens. Environ., 235, 111463, https://doi.org/10.1016/j.rse.2019.111463.

Wijesingha, J., Moeckel, T., Hensgen, F., Wachendorf, M. (2019). Evaluation of 3D point cloudbased models for the prediction of grassland biomass. Int. J. Appl. Earth Obs. Geoinf. 78, 352359. https://doi.org/10.1016/j.jag.2018.10.006.

WMO. (1989). Calculation of Monthly and Annual 30-Year Standard Normals, WCDP-No. 10, WMOTD/No. 341. World Meteorological Organization: Geneva. 
815

816

817

818

819

820

Zhu W., Jia, S., Lv, A. 2017. W. Zhu, S. Jia, A. Lv. (2017). A time domain solution of the Modified Temperature Vegetation Dryness Index (MTVDI) for continuous soil moisture monitoring. Remote Sens. Environ., 200, pp. 1-17. https://doi.org/10.1016/j.rse.2017.07.032

Zillman, J. W. (1972). A study of some aspects of the radiation and heat budgets of the southern hemisphere oceans, meteorological study 26. Canberra, Australia: Commonwealth Bureau of Meteorology. 